This item was submitted to Loughborough's Research Repository by the author.

Items in Figshare are protected by copyright, with all rights reserved, unless otherwise indicated.

\title{
Review and ranking of crash risk factors related to the road infrastructure
}

PLEASE CITE THE PUBLISHED VERSION

https://doi.org/10.1016/j.aap.2019.01.002

PUBLISHER

(c) Elsevier

VERSION

AM (Accepted Manuscript)

PUBLISHER STATEMENT

This paper was accepted for publication in the journal Accident Analysis \& Prevention and the definitive published version is available at https://doi.org/10.1016/j.aap.2019.01.002

LICENCE

CC BY-NC-ND 4.0

\section{REPOSITORY RECORD}

Papadimitriou, Eleonora, Ashleigh Filtness, Athanasios Theofilatos, A. Ziakopoulos, Claire Quigley, and George Yannis. 2019. "Review and Ranking of Crash Risk Factors Related to the Road Infrastructure". figshare. https://hdl.handle.net/2134/36879. 


\title{
Review and ranking of crash risk factors related to the road infrastructure
}

\author{
Eleonora Papadimitriou $^{\mathbf{a}^{*} \mathbf{1}}$, Ashleigh Filtness ${ }^{\mathrm{b}}$, Athanasios Theofilatos ${ }^{\mathrm{c}}$, \\ Apostolos Ziakopoulos ${ }^{d}$, Claire Quigley ${ }^{b}$, George Yannis ${ }^{d}$
}

${ }^{a}$ Delft University of Technology, Faculty of Technology, Policy \& Management, Safety \& Security Science Section, Jaffalaan 5, 2628 BX Delft, The Netherlands

${ }^{b}$ Design School, Loughborough University, Loughborough, Leicestershire, LE11 3TU, UK.

${ }^{c}$ Chair of Transportation Systems Engineering, Department of Civil, Geo and Environmental Engineering, Technical University of Munich, Arcisstrasse 21, Munich 80333, Germany.

${ }^{d}$ Department of Transportation Planning and Engineering, National Technical University of Athens, 5 Heroon Polytechniou Str., GR-15773 Athens, Greece.

\begin{abstract}
The objective of this paper is the review and comparative assessment of infrastructure related crash risk factors, with the explicit purpose of ranking them based on how detrimental they are towards road safety (i.e. crash risk, frequency and severity). This analysis was carried out within the SafetyCube project, which aimed to identify and quantify the effects of risk factors and measures related to behaviour, infrastructure or vehicles, and integrate the results in an innovative road safety Decision Support System (DSS). The evaluation was conducted by examining studies from the existing literature. These were selected and analysed using a specifically designed common methodology. Infrastructure risk factors were structured in a hierarchical taxonomy of 10 areas with several risk factors in each area (59 specific risk factors in total), examples include: alignment features (e.g. horizontal-vertical alignment deficiencies), cross-section characteristics (e.g. superelevation, lanes, median and shoulder deficiencies), road surface deficiencies, workzones, junction deficiencies (interchange and at-grade) etc. Consultation with infrastructure stakeholders (international organisations, road authorities, etc.) took place in dedicated workshops to identify user needs for the DSS, as well as "hot topics" of particular importance. The following analysis methodology was applied to each infrastructure risk factor: (i) A search for relevant international literature, (ii) Selection of studies on the basis of rigorous criteria, (iii) Analysis of studies in terms of design, methods and limitations, (iv) Synthesis of findings - and meta-analysis, when feasible. In total 243 recent and high quality studies were selected and analysed. Synthesis of results was made through 39 'Synopses' (including 4 original meta-analyses) on individual risk factors or groups of risk factors. This allowed the ranking of infrastructure risk factors into three groups: risky (11 risk factors), probably risky (18 risk factors), and unclear (7 risk factors).
\end{abstract}

\section{Keywords}

Road infrastructure; Road safety; Risk factors; Ranking; Decision making.

\section{Introduction}

The European Union (EU) has made substantial progress towards improving road safety and reducing traffic fatalities. In the decade up to 2010 , the number of fatalities reduced by $45 \%$ and the total number of persons injured reduced by 30\% (EuroStat, 2012). However, in the present decade progress has slowed down, with the number of fatalities reduced so far only by $20 \%$ (ETSC, 2018). To further reduce the road death toll it is necessary to comprehensively

\footnotetext{
* Corresponsing author: e.papadimitriou@tudelft.nl

${ }^{1}$ At the time that this research was conducted, this author was Research Associate at the National Technical University of Athens, Greece.
} 
understand the risks involved. Safety CaUsation, Benefits and Efficiency (SafetyCube) is a European Commission supported Horizon 2020 project with the objective of developing an innovative road safety Decision Support System (DSS) (www.roadsafety-dss.eu) to enable policy-makers and stakeholders to select and implement the most appropriate strategies, measures and cost-effective approaches to reduce casualties of all road user types and all severities. It is the first DSS worldwide that provides information not only on road safety measures, but also on risk factors that induce road safety problems.

One of the most critical factors affecting road safety outcomes is road infrastructure and environment (e.g. road type, geometrical design, traffic control, lighting and weather conditions, etc.) (Elvik et al., 2009). The European Commission and the European Road Safety Observatory (ERSO) release annual reports based on macroscopic data from European the CARE database with road crash data, which include crash trends and developments related to road infrastructure (ERSO, 2016a; 2016b; 2016c; 2016d). Moreover, the PRACT EU repository ("Predicting Road ACcidents - a Transferable methodology across Europe", PRACT, 2016) contains the most recent Accident Prediction Models (APMs) and Crash Modification Factors (273 and 889 respectively) in the sphere of infrastructural road features and interventions.

In addition to these European resources, there have been several knowledge repositories worldwide that have had objectives relevant to SafetyCube:

- The CMF Clearinghouse (2013) of the U.S. Department of Transportation Federal Highway Administration, with 6,251 Crash Modification Factors (CMFs) across 19 categories of infrastructure treatments. The system exclusively features infrastructure measures and does not include any measures from the domains of human behaviour, vehicle technology or post impact care, nor does it provide any assessment of road safety risks.

- The Road Safety Engineering Toolkit (Austroads, 2018), designed as a reference tool for road engineering practitioners in state and local governments, and including 67 types of infrastructural interventions, grouped in various combinations. The tool is mostly focused on textual, easily accessible descriptions of safety deficiencies and measures and there is no well-developed search engine available.

- The Road Safety Toolkit, result of collaboration between the International Road Assessment Programme (iRAP, 2018), the Global Transport Knowledge Partnership and the World Bank Global Road Safety Facility, hosts information on 58 types of interventions, 42 on infrastructure, 5 on vehicle safety, and 11 on behaviour. The Toolkit is focused on common language advice on treatments across various fields of road safety work - excluding post impact care.

The existing literature and data available in the above resources indicate that there are patterns of persistent road safety problems related to the road infrastructure and environment in the European countries and beyond, particularly as regards rural roads. This raises the need for further insight into the identification of specific critical infrastructure risk factors and their impact on road safety outcomes. However this is not possible through the analysis of the limited available macroscopic data as in ERSO, nor through the consideration of existing CMFs, that reflect the impact of countermeasures on risks and not always the magnitude and significance of the risks themselves.

In this context, the SafetyCube project aimed to identify, analyse in-depth and rank road infrastructure management, design, traffic control and environmental factors that affect road safety outcomes, and integrate the results in the road safety DSS. The objective of this paper is 
to present a review and comparative assessment of a variety of infrastructure related risk factors, with the explicit purpose of ranking them based on how detrimental they are towards road safety outcomes (i.e. crash risk, frequency and severity). This evaluation was conducted by examining studies from the existing literature, selected and analysed on the basis of a dedicated common methodology.

\section{Methodology}

Within the SafetyCube project 'risk factor' refers to any factor that contributes to the occurrence or the consequences of road crashes. Risk factors can have a direct influence on the risk of a crash occurring, on the consequences of the crash (severity), or more indirectly by influencing a Safety Performance Indicator (SPI). SPIs have in recent years been taken into consideration to quantify the road safety level (Gitelman et al., 2014). SPIs include driving perceptions and behaviour, e.g. speeding, risk perception, discomfort, reaction time, lane positioning and so on. These metrics give an indication of safe (or unsafe) driving behaviour. The most appropriate SPIs to be considered in the analysis are those for which there is scientific evidence of an association with increased crash risk.

For the analysis infrastructure related risk factors, a dedicated methodology was developed as follows (Martensen et al. 2017, 2018):

- A taxonomy of risk factors was created, in order to systematically classify areas and topics to be analysed.

- A stakeholders' consultation was carried out in order to identify user needs from the DSS and "hot topics" in the field of infrastructure safety.

- A methodology was developed for searching the literature and identifying the most relevant, high quality and recent studies;

- Moreover, tools were developed in order to analyze studies and assess their findings.

These are described in the following sections.

\subsection{A taxonomy of infrastructure risk factors}

The purpose of creating a taxonomy was to identify relevant topics covering all aspects of infrastructure and road environment risk factors, and structure them in a meaningful way (e.g. hierarchically, in general topics and specific topics), in order to serve as the back-bone of the analysis. At the beginning of the project, a comprehensive list of risk factors specific to the road infrastructure was created by means of a review, critical assessment and synthesis of taxonomies available in several key publications (e.g. ERSO, 2016; Elvik et al. 2009; CEDR, 2008; ROSEBUD, 2006; SUPREME, 2007, OECD/ITF, 2012; PRACT, 2016; iRAP, 2016). The list was further reviewed and adjusted by a group of 25 experts involved in the 'infrastructure' Work Package of SafetyCube, all renowned experts with considerable experience in road infrastructure safety. Moreover, the taxonomy was discussed during a dedicated workshop with key European and international road infrastructure stakeholders (see also section 2.2) who provided feedback and suggestions for improvement. On the basis of the above, a hierarchical taxonomy of infrastructure elements and relevant risk factors was compiled. Further slight adjustments were made during the project on the basis of comments from the Quality Assurance procedures (see section 2.4) and the formal project external reviews. 
The entire taxonomy of infrastructure risk factors utilised in the SafetyCube project is not presented here for economy of space and the reader is referred to Appendix A of this paper, as well as to Filtness \& Papadimitriou (2016) and Usami et al. (2017). Ten categories of infrastructure elements were firstly considered, and then 16 general risk factors with 59 specific risk factors were assigned to the different infrastructure elements. The 10 infrastructure elements that are included are as follows:

- Exposure (e.g. traffic flow, traffic composition)

- Road type

- Road surface

- Road environment (e.g. weather, lighting)

- Presence of work zones

- Alignment - road segments,

- Cross-section - road segments,

- Traffic control - road segments,

- Alignment - junctions

- Traffic control - junctions.

Detailed risk factors and their definitions can be found in Appendix A.

It is noted that the SafetyCube project also covers, in separate taxonomies, behaviour risk factors (e.g. speeding and inappropriate speed, driving under the influence of alcohol/drugs, fatigue, distraction or inattention, risk-taking and aggressiveness, personal factors etc.) and vehicle related risk factors (e.g. crashworthiness, protective equipment, technical defects/maintenance etc.). This paper focuses on the results concerning the infrastructure topics taxonomy; for related results on behavioural and vehicle factors the reader is referred to AignerBreuss et al. (2017), Hermitte et al. (2016).

\subsection{Identification of "hot topics"/stakeholders' consultation}

The project identified a core group of stakeholders from government, industry, research, and consumer organizations covering all the three road safety pillars: vehicle, infrastructure, road user. Several workshops took place during the first months of the SafetyCube project to engage stakeholders and identify key research topics addressing road safety; these are described in detail in Usami et al. (2017).

A more dedicated workshop was carried out with the participation of 12 road infrastructure stakeholders on February 22nd, 2016, in Brussels (SafetyCube, 2016). The participants included representatives of the European Commission Innovation and Networks Executive Agency (EC-INEA), the European Commission Directorate-General for Mobility and Transport (EC-DG-MOVE), the European Road Assessment Programme (EURORAP), the European Association of Operators of Toll Road Infrastructures (ASECAP), the European Transport Safety Council (ETSC), the Polis network for city cooperation, the Fédération Internationale de l'Automobile (International Automobile Federation - FIA), the Belgian Road Research Centre (BRRC) and Belgian regional authorities. The objectives of the workshop were the analysis of infrastructure stakeholders' needs for the DSS, and selecting "hot topics" in particular for the infrastructure related risk factors.

The "hot topics" identification process was the following: a complete list of priorities identified through the initial (previous) consultations was examined and the topics were rated for relative importance by stakeholders, both as regards the general areas and the specific topics within each area. Four main areas were prioritised in the following order of importance: (1\&2) Urban 
road safety measures \& Self-explaining and forgiving roads (equally rated), (3) Road safety management, (4) ITS applications. The top rated specific risks and measures ("hot topics") for each area are shown in Table 1. Consequently, the SafetyCube analyses have taken this ranking into account and placed special emphasis on providing sound evidence for these topics.

***Table 1 to be inserted here***

\subsection{Assessment of risk factors}

The aim of the development of a common methodology was to collect information for each risk factor in a uniform way to allow for the ranking of risk factors in a standardised manner. This included developing a literature search strategy, a standardised 'coding template' to record key data and metadata from individual studies, and concrete guidelines for summarising the findings per risk factor.

Collating information from a variety of studies, each of which may use different underlying theories, designs and methods, represented a big challenge. Therefore the approach and 'coding template' developed were designed to be flexible enough to capture important information, but also facilitate the comparison between studies. These documents and the associated instructions and guidelines can be found in Martensen et al. (2017).

\subsubsection{Literature search and study selection}

The literature searches were carried out between May and September 2016. The literature search, study selection, coding and analysis for each risk factor were carried out within the same SafetyCube partner organisation. The process was documented in a standard format to make the gradual selection of relevant studies transparent and allow replication of the analysis. The main databases used to search for studies on infrastructure risk factors were the following: Scopus, TRID, Google Scholar, ScienceDirect. Taylor \& Francis Online, Springer Link.

The aim of the search was to find studies that provided an estimate of the risk of being involved in a crash due to the presence of the risk factor. However, while the actual occurrence of crashes can be seen as the ultimate outcome measure for road safety, SPIs have been also considered in order to enhance the understanding of the effects of risk factors. This applied especially in cases where crash outcomes (crash frequency/risk, crash severity) were not adequately examined in existing studies. For instance, for three risk factors there was no study found with crash risk as the outcome variable.

For some risk factors the literature search yielded an excessive number of related studies and therefore additional selection criteria were adopted. Furthermore, on major and well-studied infrastructure risk factors, meta-analyses were available and these were prioritised in the selection. While the aim was to include as many studies as possible for as many risk factors as possible, it was simply not feasible, given the scope and resources of the project, to examine all available studies for all risk factors and their variants. The general criteria for prioritising studies to be selected were based on the following guideline:

- Existing meta-analyses (the studies already included in the meta-analysis were not reviewed again);

- Most recent studies;

- High quality of studies (robust analysis methods and substantiated findings) 
- Country origin: Europe before North America/Australasia before other countries

- Importance: number of citations

- Language: English

- Peer reviewed journals

According to the level of detail of the topic and the history of research in the field, the exact approach to prioritisation and eventual number of studies found eligible for analysis varied.

A challenge within the task of identifying studies to be included in the DSS was to distinguish between studies concerning risk factors or countermeasures. A 'duality' exists between infrastructure risks and countermeasures. For instance, 'medians' may be analysed from a risk factor viewpoint (e.g. whether the absence of a median increases crash risk) or from a countermeasure viewpoint (e.g. whether the installation of a median reduces crashes). This is also reflected to the analysis methods applicable in each case; the absence of a median may be typically studied through a cross-sectional design (i.e. comparing the safety level of roads with and without medians) or through a before-and-after analysis design (i.e. estimating the crash modification factor of installing a median in a given road). In this research, focus was placed on cross-sectional study designs, which are more directly oriented towards risk estimation. However, studies which estimate the effects of a measure or intervention were also considered, in case there was a direct 'duality' of the effect (e.g. in case of curve radius).

\subsubsection{Study coding and quality control}

A template was developed to capture relevant information from each study in a manner that this information could be uniformly reported and shared across topics within the overall SafetyCube project. The coding template was designed to accommodate the variety and complexity of different study designs. For each study the following information was coded:

- Level of taxonomy.

- Basic information of the study (title, author, year, source, origin, abstract)

- Road user groups examined.

- Study design.

- Measures of exposure to the risk factor.

- Measures of outcome (e.g. number of injury crashes).

- Type of effects (i.e. the type of numerical / statistical metrics used in a given study to quantify the between exposure to a risk factor and the related road safety outcome).

- Effects (including corresponding statistical measures of accuracy, e.g. confidence intervals).

- Study limitations.

- Summary of the information (different from the original study abstract).

For the full list of information provided per study see Martensen et al (2017). Completed coding templates (one per study) were uploaded to a relational database which serves as the back-end repository of the DSS.

Even though the instructions for coding were exhaustive, these still allowed room for interpretation e.g. which design describes the study the best (if not mentioned by author), which metrics to include or exclude, what are essentially the limitations of the study etc. Therefore, a quality control procedure was established in which all risk factors were allocated to a primary and secondary coding partner. The primary coding partner undertook the literature search, selected the papers for coding and coded these studies. The first few coded studies for each topic where shared between primary and secondary coding partners to confirm coding decisions. Once there was agreement on the coding of the first studies, the rest of the studies 
were coded by the primary partner. Nevertheless, complicated studies encountered at any stage were to be discussed between the primary and secondary coding partner so as to reach consensus. Coders had the opportunity to have several studies checked if they were uncertain.

\subsubsection{Synopses and ranking of risk factors}

The synthesis of studies for each topic were made available in the form of a 'synopsis' document including the main findings for each risk factor; these were summarized either through a meta-analysis or other type of comprehensive synthesis of the results, as is detailed below (Martensen et al., 2017).

A meta-analysis is a statistical technique used to combine the results of several individual studies, in a single quantitative estimate, as long as they fulfil the following criteria: (i) a sufficient number of individual effects is examined, (ii) the designs and sampling frames of the individual studies are similar, and (iii) the outcome indicators of each study are the same (e.g. a percentage reduction, an odds-ratio, a linear slope etc.). The theoretical background of metaanalyses is given in several studies (Berkey et al., 1995; Elvik \& Bjørnskau, 2017; Van Houwelingen et al., 2002; Viechtbauer, 2016). Furthermore, meta-analyses have been widely implemented in several road safety studies in the past, such as in Elvik (2001), Elvik et al. (2009), Roshandel et al. (2015), Theofilatos et al. (2017), however mostly as regards road safety countermeasures.

Another type of comprehensive synthesis technique is the vote-count analysis, which functions as follows: all quantitative effects of the considered studies are assessed as positive or negative towards road safety and are given a corresponding vote. Then the votes are counted to determine the impact of the risk factor under examination. This technique may be a useful alternative when dealing with heterogenous study designs or different outcome indicators in different studies. In case neither a vote-count nor a meta-analysis was possible, a review-type analysis was undertaken to provide a qualitative overview of the studies findings for the examined risk factor.

For some risk factors, it was eventually possible to code only a few studies (these are included in the DSS), but there was not enough information to write a synopsis. And for some risk factors, in addition to the coded studies, the synopsis also contains contextual information from sources that could not be coded due to lack of a particular study design or quantitative estimates (e.g. literature review papers or qualitative studies).

The synopses aim to facilitate different end-users: decision-makers looking for global results, as well as scientific users interested in detailed results and methodological aspects. Therefore, they contain sections targeted at different end-users and can be read independently. The structure of each risk factor synopsis is as follows:

- Summary (2 pages): abstract, overview of effects, analysis methods, notes on transferability.

- Scientific overview (5 pages): short synthesis of the literature, overview of the available studies, description of the analysis methods, analysis of the effects (meta-analysis, votecount table or review-type analysis).

- Supporting document (no page limit): details of literature search, detailed comparison of available studies. 
The final step of this research was the ranking of risk factors and for that purpose a colour code scale was created. The colour code indicates how important this risk factor is in terms of the amount of evidence demonstrating its impact on road safety (crash risk, frequency or severity):

- Red: Risky. Consistent results showing an increased risk of crashes or injuries when exposed to this risk factor.

- Yellow: Probably risky. Some evidence that there is increased risk when exposed to this risk factor, but results are not consistent. This could be because while the majority of studies demonstrate a risk, there may be some studies with inconsistent results. Or, studies indicate a risk but are few in number or have methodological weaknesses.

- Green. Probably not risky. Studies consistently demonstrate that this risk factor is not associated with increased crash risk, frequency or severity.

- Grey: Unclear. Studies report opposite effects. There are few studies with inconsistent results, or few studies with only weak indication or risk.

\subsubsection{Quality assurance procedures}

In addition to the quality control of the study coding described in Section 2.3.2, and in order to minimize uncertainty and subjectivity in the results, a thorough quality assurance procedure was established following the compilation of the draft synopses, with the following individual steps:

- Each Synopsis was initially reviewed internally by SafetyCube Task and Work Package Leaders, and other partners different than the original authors before submission.

- Key project Deliverables containing the latest versions of findings were externally reviewed before submission by selected road safety experts and reviews/additions were made accordingly.

- A Quality Assurance Committee, consisting of eight senior experts from the SafetyCube partner institutes, guided and coordinated a subsequent expert review of all synopses before their upload to the DSS and changes were made accordingly, including recommendations for colour code change.

- The Quality Assurance Committee also coordinated a final synopsis abstract and colour code consistency check, among all synopses, by the same senior expert.

\section{Results}

\subsection{Descriptive statistics of the studies analysed}

In total, for the 59 risk factors of the taxonomy, 243 studies were coded; in several studies, information for more than one risk factor was available. The studies originated from 75 different publication sources, the majority of which were journal papers, and a smaller number from other sources (e.g. iRAP reports, conference proceedings). Over half of the coded studies were from either the journal Accident Analysis \& Prevention or from Transportation Research Board (TRB)-related publications (i.e. the Transportation Research Record journal and the TRB annual meeting). Figure 1 shows the range of publication years for the coded studies. It can be seen that about half of the studies were published within the last 5 years (i.e. since 2012) and the majority $(75 \%)$ were published within the past 10 years (i.e. since 2007 ).

***Figure 1 to be inserted here***

Figure 2 highlights the countries of origin of the coded studies; nearly half of the studies originated from the USA (49\%), with another $28 \%$ originating from Europe. The remaining 
studies were from different countries across the world (with a few studies originating from more than one country, hence the sum of studies in Figure 2 exceeds the number of coded studies).

***Figure 2 to be inserted here***

Across the 243 coded studies, a range of different methods were used. Observational studies made up for $75 \%$ of the total number of studies; these entail no manipulation from the researcher and focus on the natural occurrence (distribution) of exposure and outcome. Cross-sectional designs were found in a large number of studies (54\%), while case-control study designs were the $3^{\text {rd }}$ most frequent type. In about half of the studies, more than one method was used, and the most frequent combination was observational / cross-sectional study (featured in $34 \%$ of the studies). It was interesting to note that the risk factors related to adverse weather conditions in particular (rain and snow/ice/low temperatures) were largely analysed through time-series methods.

Table 2 further shows that the more frequent type of outcome examined in the selected literature were crash and injury risk or rate, followed by vehicle position, speed, acceleration, and other SPIs which reflect more indirect ways to gauge road safety outcomes.

$* * *$ Table 2 to be inserted here***

The variable used in the coded studies to express the exposure to the risk factor was often the risk factor itself e.g. ramp length. For some risk factors, the exposure variable differed slightly from the risk factor. For instance, for the risk factor 'undivided road', the most common parameter of exposure was 'presence of median' ('yes': not exposed to the risk factor, or 'no': exposed to the risk factor). For certain risk factors, there was more than one possible variable of exposure defined across the coded studies e.g. for road surface 'inadequate friction' risk factor, there were several exposure variables found: 'pavement friction', 'pavement maintenance condition', 'road surface type', 'surface contaminants' (e.g. snow, wet etc. This highlights that some infrastructure risk factors were more complex to analyse than others.

\subsection{Analysis of risk factors effects}

Ultimately thirty-nine (39) synopses on road infrastructure risk factors have been created for inclusion in the DSS. This resulted from merging some of the risk factors for which there were not enough studies to analyse them separately. Overall, 4 original meta-analyses, 19 vote-count analyses and 16 review-type analyses were carried out (thus totalling 39 analyses). A detailed assessment of infrastructure related risk factors is presented in Table 3.

***Table 3 to be inserted here ${ }^{* * *}$

The four original meta-analyses concerned the risk factors 'workzone length', 'workzone duration', 'ramp length' and 'acceleration / deceleration lane length' (Theofilatos et al., 2017; Papadimitriou and Theofilatos, 2017). Not all meta-analysis results were statistically significant; for instance, it was found that insufficient workzone length did increase crash risk, whereas workzone duration had non significant results on crash risk. Detailed results of these meta-analyses appear on Table 4. The meta-analysis estimates refer to the beta coefficients of linear models on the effect of the examined risk factor to crashes. In each meta-analysis, the beta coefficients were drawn from each coded study and then the meta-analysis estimate was calculated as the overall effect of the risk factor. In addition to the four original meta-analyses, 
for certain risk factors, e.g. curve radius and road surface friction, existing meta-analyses available in the literature were coded.

\section{***Table 4 to be inserted here***}

In the vote-count analyses undertaken results were presented in Tables showing the proportion of reported effects across all the studies found for the examined risk factor, classified as (i) a statistically significantly increase in risk, (ii) a significant decrease in risk, and (iii) no significant difference (i.e. either a non-significant result or statistical analysis was not undertaken). Table 5 shows an example of a vote-count Table from the synopses on risk factor \#26 'presence of tunnels'. This was based on the analysis of 8 studies and 44 effects in total; it can be seen that different outcome variables were examined in the different studies. It is also worth mentioning that the type of effects / metrics used in the 8 studies included slopes (beta coefficients), odds-ratios, absolute difference, percentage difference. These studies features could not allow for a meta-analysis.

\section{$* * * *$ Table 5 to be inserted here ${ }^{* * *}$}

Figure 3 provides an summary of the results of all the vote-count analyses, through an overview of the proportion of the negative, positive and non-significant effects found for each risk factor. The risk factors with the greatest proportion of negative effects on safety (i.e. $>70 \%$ over $70 \%$ of the effects in the selected studies) were 'distribution of flow over arms at junctions' and 'high grade' (i.e. uphill or downhill). 'Traffic volume' and 'congestion' were found to be the two risk factor topics which resulted in the highest proportions of positive effects on safety. In both cases (i.e. $>65 \%$ of the effects in the selected studies showed a reduction of crash risk). This is not surprising, as both high traffic volume and traffic congestion will lead to lower vehicle speeds, which in turn will reduce the risk of crashes (Taylor et al, 2000).

***Figure 3 to be inserted here***

Some risk factor had a high number of non-significant results, particularly topics such as 'rain', 'secondary crashes', 'different junction types' and 'absence of road markings/crosswalks', (i.e. $>50 \%$ of the effects in the selected studies were non-significant). Therefore, for these risk factors, it is less clear from the vote-count analysis whether they have an overall positive or negative on safety. In a few cases, e.g. 'rain', there were significantly different effects found for different road user groups. In order to determine the final colour code assigned to each risk factor, more than the results of the vote-count analysis were considered (e.g. quality of studies, transferability potential).

For the final 16 synopses where neither a meta-analysis nor a vote-count could be undertaken, a review-type analysis was instead carried out. Table 6 shows an example of review type analysis carried out for the risk factor \#30 'number of lanes'. In this case, the number of eligible studies (and the effects reported therein) was small and a vote-count would not be meaningful. Nevertheless, the evidence was sufficiently consistent and statistically significant to assign the colour code 'red' (risky) to this risk factor.

$* * *$ Table 6 to be inserted here $* * *$

\subsection{Ranking of risk factors}


Figure 4 presents the risk factors classified by colour code. In total eleven (11) risk factors were given the colour red, indicating that there is consistent evidence that this risk factor has a negative effect on road safety. Additionally, three (3) other risk factors were characterised red for specific road users, namely 'Traffic Composition (Vulnerable Road Users (VRUs) only)', 'poor visibility - darkness' (pedestrians only) and 'adverse weather - rain (motor vehicles only)'. For the other road user groups of each of these three risk factors, a different colour code was assigned, as risks were found to be less severe for them.

$$
\text { ***Figure } 4 \text { to be inserted here*** }
$$

The risk factors in the red category are spread across various infrastructure elements. This is a particularly important finding for the following risk factors, that were also identified as hot topics: workzone length, low curve radius, absence of paved shoulders, narrow shoulders.

On the other hand, some risk factors allocated a red colour code were not identified by stakeholders as being hot topics. There is a degree of discordance between stakeholder perception or opinion of which infrastructure factors pose most risk and the scientific evidence. This may be due to the fact that different stakeholders often have different specific areas of interest, and therefore not all risk factors are of equal importance to all stakeholders. Alternatively, stakeholders may be aware of the risk but feel it is already controlled for in their specific area of activity, or not possible to control for.

A further eighteen (18) risk factors were considered to be yellow, demonstrating some evidence of negative impact to road safety, however, problems of weak findings, inconsistency between studies or few studies means that the evidence was not considered sufficient to be colour-coded red. More risk factors were coded yellow than any other rating. This likely reflects the growing field of road safety research, i.e. these factors are risky but at the moment not enough research of high quality has been conducted to confirm this. Several risk factors allocated a yellow colour code are among the identified hot topics.

Seven (7) risk factors were considered to be grey, indicating that there was not enough evidence to draw a clear conclusion about their impact on road safety. This clearly reflects gaps in road safety scientific literature. It would be beneficial for future research to consider addressing each of these factors, especially since several of them are hot topics. This also demonstrates that the scientific literature is not currently meeting all the needs of road safety stakeholders for evidence-based information.

In Table 3, synopsis results are classified within each of the infrastructure element area, with the specific risk factors within this area ranked by their colour code. The infrastructure areas 'alignment-junctions' and 'cross-section road segments' have the greatest number of risk factors with a red colour code. In each case, the specific road types where the impacts of these risk factors have been studied are provided. Finally, the remarks column indicates particular conditions where an effect was maximized or differentiated from the mean, and any other remarks necessary.

The majority of the risk factors were investigated in all road types (i.e. motorways, urban and rural roads). Ten risk factors were examined both on rural and urban roads, whereas motorways and rural roads concerned eight risk factors. Four risk factors (i.e. traffic flow, secondary crashes, ramp length, acceleration/deceleration lane length) were studied only on motorways, 
while the effect of traffic composition for VRUs and densely spaced junctions were analysed only on urban roads.

As mentioned previously, it was not possible to produce a synopsis for all specific risk factors listed in the taxonomy. This was due to difficulties of finding enough relevant studies. Often this was due to the fact that the risk factor examined was conceptually very closely associated with a related measure (e.g. the absence of an infrastructure element was examined in the literature through before-and-after studies on its implementation, e.g. the case of insufficient signage in workzones). Such topics were dealt with in subsequent steps of SafetyCube, which dealt explicitly with the measures deployed to improve road infrastructure defects or problems.

The following specific risk factors were identified as hot topics by stakeholders but could not have a synopsis: insufficient signage (workzones), vertical curve radius, poor sight distance vertical curve, poor road readability, misleading or unreadable traffic signs. This further demonstrates that there are some issues for road safety practitioners and policy makers which the scientific community has not yet adequately investigated. Although there is not enough evidence to produce a synopsis for each of these risk factors, in some cases there were a few studies found (e.g. insufficient signage at workzones) and these have been coded and included in the DSS.

\section{Discussion}

The work carried out for the SafetyCube project was motivated by the need to capture and present the effects of a variety of risk factors involved in road safety. For that reason, each synopsis includes all relevant coded studies, which may examine more than one risk factors (e.g. through a statistical model combining various geometrical and environmental risk factors). Moreover, each synopsis contains information and discusses the potential combination and interaction of other related risk factors as well (confounding factors). It is important to note that, within the SafetyCube DSS, links between risk factors and measures were established. In that context, a measure could tackle multiple risk factors at the same time. Therefore, it could reasonably tackle their potential combination as well.

The question of transferability of findings was examined with particular emphasis in each synopsis. The information given in this paper and the DSS is drawn from studies conducted in many countries over a long period, which might raise the question of whether the results of a study made in one country at a certain time can be transferred to a different country at a different time. Overall, transferability conditions are considered good if there are many studies, reported in many countries, and showing consistent results. This is known as the concept of the 'range of replications', which indicates both the number of countries in which studies had been made and the length of time during which studies had been made (Elvik, 2012). It has been shown (Elvik, 2012; Yannis and Papadimitriou, 2018) that as new countries contribute knowledge, the mean effect of a risk factor is stabilized over time (e.g. the effect of road lighting on injury crashes). This kind of stability supports a belief in transferability when countries and study years are diverse, and all assessments of transferability in the SafetyCube synopses were based on that concept. Based on the sample of countries from which the reviewed studies were conducted (predominantly European, Australian, and North American), the results of the analyses may be considered generally transferable within industrialized countries.

On the other hand, several hot topics were ranked as grey, suggesting that the scientific literature is not currently meeting the needs of infrastructure stakeholders in all cases. Even 
when results are inconclusive, DSS users may identify specific studies among those coded that are closer to their context or local conditions.

Some limitations of this work should also be noted. The process of allocating colour codes was related to both the magnitude of risk observed and the level of evidence for this. It is possible that a risk factor currently with a yellow colour code may be eventually proved to have more detrimental impact on road safety than a risk factor currently coded red, if there was limited evidence of the risk at the time of analysis. Because of this, it is important to keep in mind that road safety benefits may be expected from tackling both red and yellow infrastructure risk factors. An added value of the present research lies in demonstrating the lack of maturity of road safety research in several aspects of infrastructure related risk factors.

The features of the literature search strategy and the quality of the studies identified should also be kept in mind. Due to time and resources constraints, prioritising of study coding was necessary for risk factors with many identified studies. Across all risk factors, priority was given to studies which considered crashes over SPIs. The approach focused on studies with the highest methodological quality, however, it is possible that not all methodological approaches relevant for analysing a given risk factors have been included. Finally, within the considered literature, crash risk and crash frequency are much more commonly studied than crash severity. For some risk factors this makes it difficult (or impossible) to consider the implications for injury causation.

The common approach of using the TRID search database was adopted since this is a rich source of information on the relationship between infrastructure layout and crashes/safety. However, this resulted in a high number of US studies reviewed. Nevertheless, the studies identified were of sufficiently high quality to inform understanding of the risk factor.

Emerging transport developments, such as the upcoming challenges from autonomous vehicles, were not explicitly considered at this stage, as they need to be first sufficiently evaluated with real data (instead of simulations etc.) before drawing any conclusions. The analysis focused on existing recent research in the field of infrastructure safety, which will remain highly relevant in the coming years, despite the expected (but largely unknown) impact of mid-term future changes.

Subsequent to the current work, the SafetyCube project has identified measures to address the identified risk factors. Priority was placed on investigating measures aimed to mitigate the risk factors identified as red. Additionally, CBAs for the most effective measures has been conducted to provide decision-makers with a tool to reach informed decisions that can be prioritized. The coded studies and synopses for the infrastructure risk factors (and measures) are all accessible to the users of the DSS (www.roadsafety-dss.eu). Overall, the DSS may support evidence-based policy making at European, national and local level. When deciding how to allocate limited resources for improving road safety, the DSS provides increased awareness of the relative evidence for each risk factor, the related road safety measures and their cost-effectiveness.

\section{Acknowledgements}

This paper is based on work carried out within the SafetyCube project of the H2020 programme of the European Commission (Grant number 633485). The information and views set out in this paper are those of the authors and may not reflect the official opinion of the European 
Commission. The authors would like to thank all the partners involved in the "infrastructure" work package 5 of SafetyCube, namely TOI-Norway, VIAS-Belgium, KfV-Austria, CTL-Italy, SWOV-The Netherlands, AVP-Slovenia, and ERF-Belgium for their valuable contribution. Special thanks are addressed to the road infrastructure stakeholders for their valuable feedback and suggestions during the SafetyCube workshops. 


\section{References}

Aigner-Breuss, E., Kaiser, S., Usami, D.S., Reed, S. \& Weijermars, W., Inventory of Road User Related Risk Factors and Safety Measures, Deliverable 4.4 of the H2020 Project SafetyCube, 2017.

Austroads, Road Safety Engineering Kit, Australia, (www.engtoolkit.com.au), 2018 (Accessed 30-08-2018).

Berkey, C. S., Hoaglin, D. C., Mosteller, F., \& Colditz, G. A., A random-effects regression model for meta-analysis. Stat Med 14(4), 1995, 395-411.

CEDR, Best practice on cost effective road safety infrastructure investments, Paris, Conference of European Directors of Roads (CEDR), 2008.

CMF Clearinghouse, FHWA, US Department of Transportation (www.cmfclearinghouse.org). 2018, Accessed 30-08-2018.

Elvik, R., Area-wide urban traffic calming schemes: a meta-analysis of safety effects. Accid. Anal. Prev 33, 2001, 327-336.

Elvik, R., The range of replications technique for assessing the external validity of road safety evaluation studies. Accid. Anal. Prev. 45, 2012, 272-280.

Elvik, R., \& Bjørnskau, T., Safety-in-numbers: a systematic review and meta-analysis of evidence. Saf. Sci. 92, 2017, 274-282.

Elvik, R., Hoye, A.; Vaa, T., Sorensen, M., The Handbook of Road Safety Measures. $2^{\text {nd }}$ Edition, 2009, Emerald, Bingley, UK

ETSC (2018). Ranking EU progress on road safety, $12^{\text {th }}$ Road Safety Performance Index Report. European Transport Safety Council, Brussels, June 2018.

European Road Safety Observatory, ERSO, Traffic Safety Basic Facts 2016-Urban Areas, 2016a.

European Road Safety Observatory, ERSO, Traffic Safety Basic Facts 2016-Motorways, 2016b.

European Road Safety Observatory, ERSO, Traffic Safety Basic Facts 2016-Junctions, 2016c.

European Road Safety Observatory, ERSO, Traffic Safety Basic Facts 2016-Roads Outside Urban Areas, 2016d..

Filtness A. \& Papadimitriou E. (Eds), Identification of Infrastructure Related Risk Factors, Deliverable 5.1 of the H2020 Project SafetyCube, 2016.

Gitelman, V., Vis, M., Weijermars, W. \& Hakkert, S. (2014). Development of road safety performance indicators for the European countries, Adv. Soc. Sci. Res. J. 1 (4), 2014, 138-158. 
Hermitte T. and al. (2016), Identification of Vehicle Related Risk Factors, Deliverable 6.1 of the H2020 Project SafetyCube.

iRAP Road Safety Toolkit (http://toolkit.irap.org/), 2018, Accessed 14-06-2018.

Loenis, B. Schermers, G., van Petegem, J.W.H., Larger Number of Lanes, European Road Safety Decision Support System, developed by the H2020 Project SafetyCube. Retrieved from www.roadsafety-dss.eu, 2016, on 20 November 2018.

Martensen, H. et al., Methodological Framework for the Evaluation of Road Safety Measures, Deliverable Number 3.3 of the H2020 Project SafetyCube, 2017.

Martensen H.; Diependaele K; Daniels S.; Van den Berghe W.; Papadimitriou E.; Yannis G.; Van Schagen I.; Weijermars W.; Wijnen W.; Filtness A.; Talbot R.; Thomas P.; Machata K.; Aigner Breuss E.; Kaiser S.; Hermitte T.; Thomson R.; Elvik R., The European road safety decision support system on risks and measures, Article In Press Accid. Anal. Prev. 2018.

OECD/ITF, Sharing Road Safety: Developing an International Framework for Crash Modification Functions. Paris, 2012.

Papadimitriou, E., and Theofilatos, A. (2017). Meta- analysis of crash-risk factors in freeway entrance and exit areas, J. Transp. Eng. Part A Syst. 143 (10), 2017, 04017050.

PRACT, Predicting Road Accidents - A Transferable Methodology Across Europe (http://www.pract-repository.eu/), 2016.

ROSEBUD, Examples of Assessed Road Safety Measures-A Short Handbook. ROSEBUD Consortium, Research Project, 2006, European Commission; Brussels.

Roshandel, S., Zheng, Z., \& Washington, S., Impact of real-time traffic characteristics on freeway crash occurrence: systematic review and meta-analysis. Accid. Anal. Prev. 79, 2015, 198-211.

SUPREME, Handbook for Measures at the Country Level. SUPREME Consortium, Research Project, 2007a, European Commission; Brussels.

SUPREME, Handbook for Measures at the European Level. SUPREME Consortium, Research Project, 2007b, European Commission, Brussels.

Taylor, M. C., Lynam, D. A., and Baruya, A., The Effects of Drivers' Speed on the Frequency of Road Accidents, 2000, Transport Research Laboratory; Crowthorne..

Theofilatos, A., Ziakopoulos, A., Papadimitriou, E., Yannis, G., \& Diamandouros, K., Metaanalysis of the effect of road work zones on crash occurrence, Accid. Anal. Prev. 108, 2017, 18 .

Usami, D.S., Papadimitriou, E., Ziakopoulos, A., Quigley, C., Katrakazas, C., Durso C. (Eds), Inventory of Assessed Infrastructure Risk Factors and Measures, Deliverable 5.4 of the H2020 Project SafetyCube, 2017. 
Van Houwelingen, H. C., Arends, L. R., \& Stijnen, T., Advanced methods in meta-analysis: multivariate approach and meta-regression. Stat. Med. 21(4), 2002, 589-624.

Viechtbauer, W., Conducting meta-analyses in R with the metafor package. J. Stat. Softw 36(3), 2010.

Yannis G., and Papadimitriou E. (Eds) The European Road Safety Decision Support System A Clearinghouse of Road Safety Risks and Measures, Deliverable 8.3 of the H2020 Project SafetyCube, 2018..

Ziakopoulos, A., Theofilatos,A., Papadimitriou, E., Yannis, G., Presence of Tunnels, European Road Safety Decision Support System, Developed by the H2020 Project SafetyCube, Retrieved fromwww.roadsafety-dss.eu, 2016, on 30 November 2018. 
Table 1. Prioritisation of "hot topics" by road infrastructure stakeholders

\begin{tabular}{|l|l|l|l|}
\hline $\begin{array}{l}\text { A. Urban road safety (detailed } \\
\text { ranking was not possible) }\end{array}$ & $\begin{array}{l}\text { B. Self-explaining } \\
\text { and forgiving roads }\end{array}$ & $\begin{array}{l}\text { C. Road safety } \\
\text { management }\end{array}$ & D. ITS applications \\
\hline Pedestrians/ cyclists & Removing obstacles & $\begin{array}{l}\text { Quality of measures } \\
\text { implementation }\end{array}$ & ISA \\
\hline Upgrade of Crossings & Introduce shoulder & $\begin{array}{l}\text { Appropriate speed } \\
\text { limits }\end{array}$ & $\begin{array}{l}\text { Dynamic speed } \\
\text { warning }\end{array}$ \\
\hline New crossings & $\begin{array}{l}\text { Alignment } \\
\text { (horizontal / vertical) }\end{array}$ & Enforcement & $\begin{array}{l}\text { ADAS and active } \\
\text { safety with V2I }\end{array}$ \\
\hline $\begin{array}{l}\text { Junctions / roundabouts } \\
\text { treatments for VRU }\end{array}$ & Sight distance & $\begin{array}{l}\text { Availability of cost- } \\
\text { effectiveness data }\end{array}$ & $\begin{array}{l}\text { Implementation of } \\
\text { VMS }\end{array}$ \\
\hline Visibility & Traffic signs & Workzones & \\
\cline { 2 - 4 } & $\begin{array}{l}\text { Raised crossings / } \\
\text { intersections }\end{array}$ & & \\
\hline
\end{tabular}


Table 2. Types of road safety outcomes examined across the selected studies.

\begin{tabular}{|l|r|}
\hline Type of Outcome & Number of Risk Factors \\
\hline Crash rate/risk & 41 \\
\hline Injury or casualty rate/risk & 11 \\
\hline Vehicle speed/acceleration & 7 \\
\hline Lateral position of vehicle & 2 \\
\hline Road user type & 2 \\
\hline Crash modification factor & 2 \\
\hline Risk perception & 2 \\
\hline Discomfort & 2 \\
\hline Vehicle-kms travelled & 2 \\
\hline Driver fault & 1 \\
\hline Braking length & 1 \\
\hline Behaviour of drivers/pedestrians & 1 \\
\hline
\end{tabular}


Table 3. Overview of synopsis results per risk factor (For interpretation of the references to colour in this table legend, the reader is referred to the web version of this article).

\begin{tabular}{|c|c|c|c|c|c|c|c|c|c|c|c|c|c|c|c|c|}
\hline \multirow{2}{*}{ 苛 } & \multirow[b]{2}{*}{ 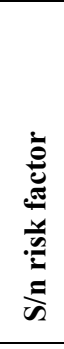 } & \multirow[b]{2}{*}{ 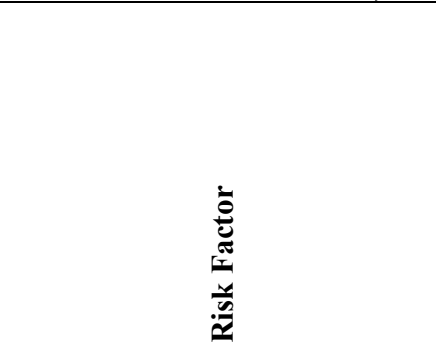 } & \multirow[b]{2}{*}{ 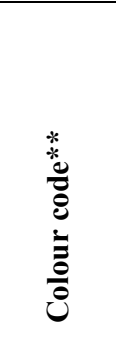 } & \multirow[b]{2}{*}{ 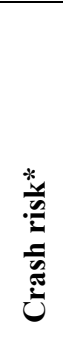 } & \multirow[b]{2}{*}{ 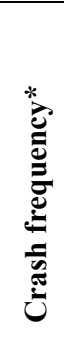 } & \multirow[b]{2}{*}{ 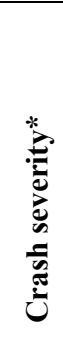 } & \multirow{2}{*}{ 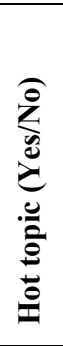 } & \multicolumn{3}{|c|}{$\begin{array}{l}\text { Road types } \\
\text { studied }\end{array}$} & \multicolumn{3}{|c|}{$\begin{array}{l}\text { Synthesis } \\
\text { method }\end{array}$} & \multirow{2}{*}{ 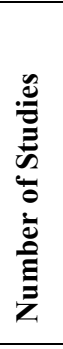 } & \multirow{2}{*}{ 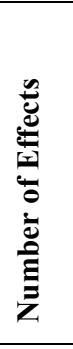 } & \multirow[b]{2}{*}{ Additional remarks } \\
\hline & & & & & & & & 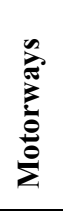 & 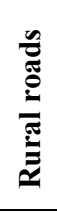 & 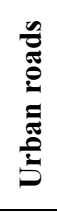 & 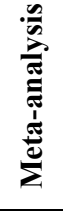 & 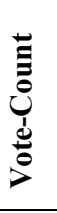 & $\overbrace{0}^{0}$ & & & \\
\hline \multirow{6}{*}{ Exposure } & 1 & Effect of traffic volume on safety & Red & $\downarrow$ & $\uparrow$ & - & $\mathrm{N}$ & $\checkmark$ & & & & $\checkmark$ & & 7 & 33 & $\begin{array}{l}\text { Multi-vehicle crashes appear to increase } \\
\text { more }\end{array}$ \\
\hline & 4 & $\begin{array}{l}\text { Risks associated with traffic } \\
\text { composition (risk to VRUs } \\
\text { only) }{ }^{* * *}\end{array}$ & Red & $\downarrow$ & $\uparrow$ & - & $\mathrm{N}$ & & & $\checkmark$ & & & $\checkmark$ & 6 & 48 & - \\
\hline & 3 & Occurrence of secondary crashes & Yellow & $\uparrow$ & - & - & $\mathrm{N}$ & $\checkmark$ & & & & $\checkmark$ & & 7 & 25 & $\begin{array}{l}\text { Long incident duration, daytime and peak } \\
\text { period incidents increase the probability } \\
\text { of a secondary crash }\end{array}$ \\
\hline & 2 & Congestion as a risk factor & Yellow & - & $\uparrow$ & - & $\mathrm{N}$ & $\checkmark$ & $\checkmark$ & $\checkmark$ & & $\checkmark$ & & 7 & 6 & $\begin{array}{l}\text { Delay or low speed is associated with } \\
\text { high crash frequency for all crash types }\end{array}$ \\
\hline & 4 & $\begin{array}{l}\text { Risks associated with traffic } \\
\text { composition (risk to HGVs } \\
\text { only)*** }\end{array}$ & Grey & $\downarrow$ & $\uparrow$ & - & $\mathrm{N}$ & $\checkmark$ & $\checkmark$ & & & & $\checkmark$ & 6 & 48 & - \\
\hline & 5 & $\begin{array}{l}\text { Risks associated with the } \\
\text { distribution of traffic flow over } \\
\text { arms at junctions }\end{array}$ & Grey & - & - & $\uparrow$ & $\mathrm{N}$ & & $\checkmark$ & $\checkmark$ & & $\checkmark$ & & 8 & 23 & $\begin{array}{l}\text { More negative effects on signalised } \\
\text { junctions than on non-signalised ones }\end{array}$ \\
\hline Road Type & 6 & Road Functional Class & Yellow & - & $\uparrow$ & $\uparrow$ & $\mathrm{N}$ & $\checkmark$ & $\checkmark$ & $\checkmark$ & & $\checkmark$ & & 5 & 15 & $\begin{array}{l}\text { For heavy track tractors, high speed } \\
\text { national roads have the greatest risk }\end{array}$ \\
\hline $\begin{array}{l}\text { Road } \\
\text { Surface }\end{array}$ & 7 & Inadequate Friction & Red & $\uparrow$ & - & $\uparrow$ & $\mathrm{N}$ & $\checkmark$ & $\checkmark$ & $\checkmark$ & $\checkmark$ & & & 16 & 15 & $\begin{array}{l}\text { Pavement surface skid resistance can } \\
\text { improve safety of urban intersections }\end{array}$ \\
\hline \multirow{3}{*}{$\begin{array}{l}\text { Road } \\
\text { environment }\end{array}$} & 13 & $\begin{array}{l}\text { Adverse weather - Rain (risk to } \\
\text { motor vehicles only)*** }\end{array}$ & Red & - & $\uparrow$ & - & $\mathrm{N}$ & $\checkmark$ & $\checkmark$ & $\checkmark$ & & $\checkmark$ & & 14 & 84 & - \\
\hline & 11 & $\begin{array}{l}\text { Poor Visibility - Darkness (risk } \\
\text { to pedestrians only)*** }\end{array}$ & Red & $\uparrow$ & - & $\uparrow$ & $\mathrm{N}$ & $\checkmark$ & $\checkmark$ & $\checkmark$ & & $\checkmark$ & & 5 & 46 & $\begin{array}{l}\text { The crash risk for pedestrian is } 2 \text { to } 4 \\
\text { times higher in darkness }\end{array}$ \\
\hline & 13 & $\begin{array}{l}\text { Adverse weather - Rain (risk to } \\
\text { all)*** }\end{array}$ & Yellow & - & $\uparrow$ & - & $\mathrm{N}$ & $\checkmark$ & $\checkmark$ & $\checkmark$ & & $\checkmark$ & & 14 & 84 & $\begin{array}{l}85 \% \text { of the studies found an increase in } \\
\text { fatal crashes, mostly in motorways and } \\
\text { rural roads }\end{array}$ \\
\hline
\end{tabular}




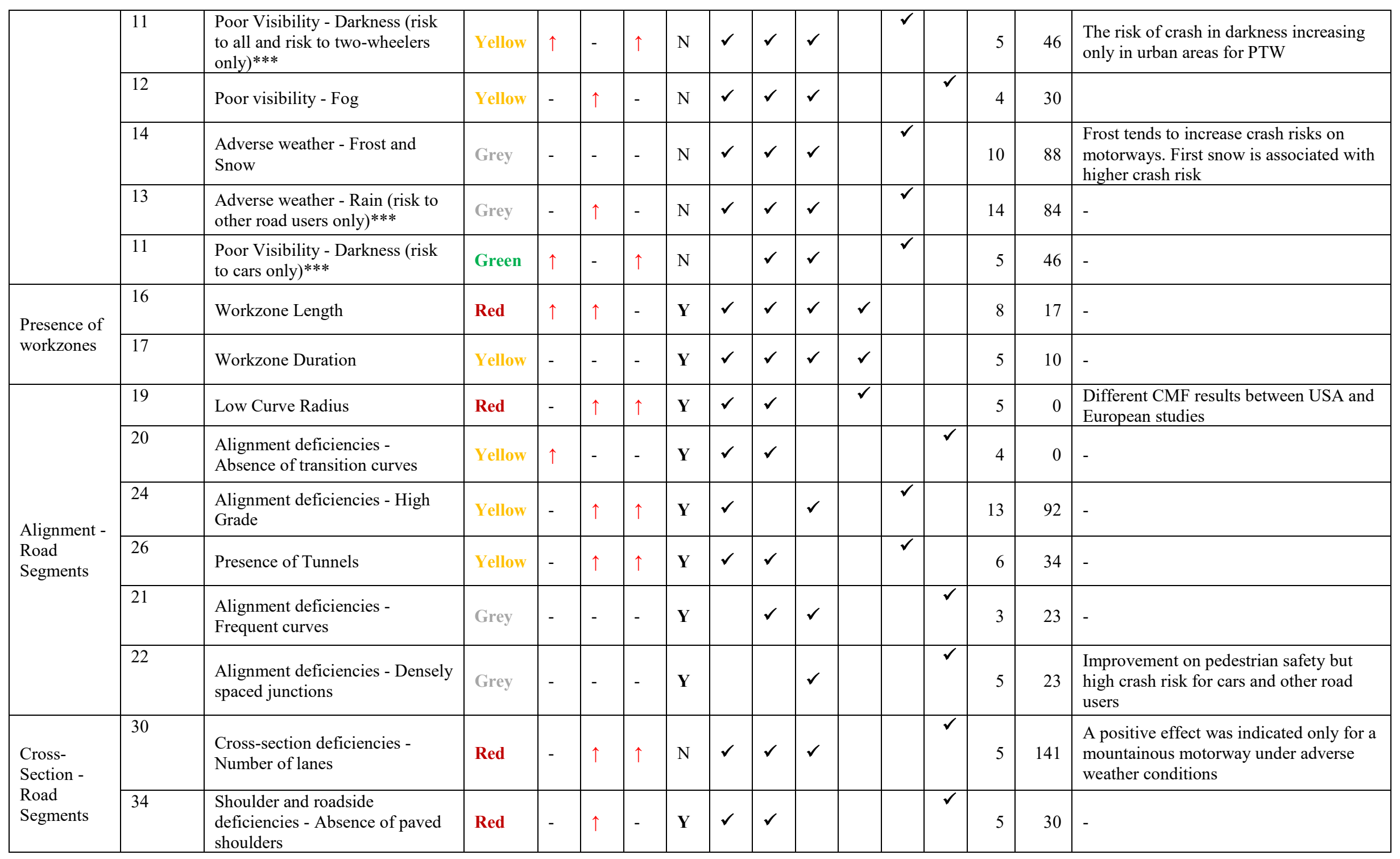




\begin{tabular}{|c|c|c|c|c|c|c|c|c|c|c|c|c|c|c|c|c|}
\hline & 35 & $\begin{array}{l}\text { Shoulder and roadside } \\
\text { deficiencies -Narrow shoulders }\end{array}$ & Red & - & $\uparrow$ & - & $\mathbf{Y}$ & $\checkmark$ & $\checkmark$ & & & & $\checkmark$ & 5 & 55 & - \\
\hline & 31 & $\begin{array}{l}\text { Cross-section deficiencies - } \\
\text { Narrow lanes }\end{array}$ & Yellow & - & $\uparrow$ & - & $\mathrm{N}$ & $\checkmark$ & $\checkmark$ & $\checkmark$ & & & $\checkmark$ & 5 & 80 & - \\
\hline & 32 & Undivided Road & Yellow & - & - & $\uparrow$ & $\mathrm{N}$ & & $\checkmark$ & $\checkmark$ & & & $\checkmark$ & 3 & 13 & - \\
\hline & 33 & $\begin{array}{l}\text { Cross-section deficiencies - } \\
\text { Narrow Median }\end{array}$ & Yellow & - & $\uparrow$ & $\uparrow$ & $\mathrm{N}$ & $\checkmark$ & $\checkmark$ & $\checkmark$ & & & $\checkmark$ & 5 & 14 & $\begin{array}{l}\text { Increased crash frequency for women } \\
\text { and older drivers. IF median width is less } \\
\text { than } 40 \text { feet the no-injury crash rate } \\
\text { decreases }\end{array}$ \\
\hline & $36,37,39$ & $\begin{array}{l}\text { Shoulder and roadside } \\
\text { deficiencies - Risks associated } \\
\text { with safety barriers }\end{array}$ & Yellow & - & $\uparrow$ & $\uparrow$ & $\mathbf{Y}$ & $\checkmark$ & $\checkmark$ & & & $\checkmark$ & & 8 & 60 & $\begin{array}{l}\text { Colliding with a steel type compared to } \\
\text { concrete type guardrail appears to } \\
\text { increase the risk of fatality, but reduces } \\
\text { the risk of injury }\end{array}$ \\
\hline & 38 & $\begin{array}{l}\text { Shoulder and roadside } \\
\text { deficiencies - Sight obstructions } \\
\text { (Landscape, Obstacles and } \\
\text { Vegetation) }\end{array}$ & Yellow & - & - & - & $\mathbf{Y}$ & $\checkmark$ & $\checkmark$ & $\checkmark$ & & & $\checkmark$ & 8 & 49 & $\begin{array}{l}\text { The wider the offsets of the trees from } \\
\text { the edge of the road pavement is on rural } \\
\text { area, the higher the crash risk }\end{array}$ \\
\hline & 28 & $\begin{array}{l}\text { Cross-section deficiencies - } \\
\text { Superelevation }\end{array}$ & Yellow & $\uparrow$ & $\uparrow$ & - & $\mathrm{N}$ & $\checkmark$ & $\checkmark$ & & & & $\checkmark$ & 4 & 32 & - \\
\hline \multirow{7}{*}{$\begin{array}{l}\text { sAlignment } \\
\text { - Junctions }\end{array}$} & 48 & $\begin{array}{l}\text { Interchange deficiencies - } \\
\text { Absence of access control }\end{array}$ & Red & - & $\uparrow$ & - & $\mathrm{N}$ & $\checkmark$ & $\checkmark$ & $\checkmark$ & & & $\checkmark$ & 4 & 9 & - \\
\hline & 51 & Risk of different junction types & Red & $\uparrow$ & - & $\uparrow$ & $\mathbf{Y}$ & & $\checkmark$ & $\checkmark$ & & $\checkmark$ & & 19 & 55 & $\begin{array}{l}\text { 4-legged junctions more unsafe than 3- } \\
\text { legged ones and roundabouts more safe } \\
\text { than intersections }\end{array}$ \\
\hline & 54 & $\begin{array}{l}\text { At-grade junction deficiencies - } \\
\text { Gradient }\end{array}$ & Red & $\uparrow$ & - & $\uparrow$ & $\mathrm{N}$ & & $\checkmark$ & $\checkmark$ & & $\checkmark$ & & 8 & 14 & $\begin{array}{l}\text { Junctions located at a (constant) grade } \\
\text { are associated with a higher fatality risk }\end{array}$ \\
\hline & 50 & $\begin{array}{l}\text { At-grade junctions deficiencies - } \\
\text { Number of conflict points }\end{array}$ & Yellow & - & $\uparrow$ & - & $\mathbf{Y}$ & & $\checkmark$ & $\checkmark$ & & $\checkmark$ & & 13 & 65 & - \\
\hline & 52 & $\begin{array}{l}\text { At-grade junction deficiencies - } \\
\text { Skewness / junction angle }\end{array}$ & Yellow & $\uparrow$ & - & $\uparrow$ & $\mathbf{Y}$ & & $\checkmark$ & $\checkmark$ & & $\checkmark$ & & 12 & 25 & $\begin{array}{l}\text { A skewed angle at intersections appears } \\
\text { to lead to a higher crash risk compared to } \\
\text { an intersection angle of } 90 \text { or near } 90 \\
\text { degrees }\end{array}$ \\
\hline & 53 & $\begin{array}{l}\text { At-grade junction deficiencies - } \\
\text { Poor Sight Distance }\end{array}$ & Yellow & $\uparrow$ & - & - & $\mathbf{Y}$ & & $\checkmark$ & $\checkmark$ & & $\checkmark$ & & 7 & 15 & - \\
\hline & 45 & $\begin{array}{l}\text { Interchange deficiencies - Ramp } \\
\text { length }\end{array}$ & Grey & - & - & $\uparrow$ & $\mathrm{N}$ & $\checkmark$ & & & $\checkmark$ & & & 8 & 10 & - \\
\hline
\end{tabular}




\begin{tabular}{|c|c|c|c|c|c|c|c|c|c|c|c|c|c|c|c|}
\hline & 46 & $\begin{array}{l}\text { Interchange deficiencies - } \\
\text { Acceleration/Deceleration lane } \\
\text { length }\end{array}$ & Grey & - & - & - & $\mathrm{N}$ & $\checkmark$ & & & $\checkmark$ & & 10 & 33 & $\begin{array}{l}\text { There is an indication that increased } \\
\text { deceleration lane length leads to more } \\
\text { crashes (although less severe) }\end{array}$ \\
\hline \multirow{3}{*}{$\begin{array}{l}\text { Traffic } \\
\text { Control - } \\
\text { Junctions }\end{array}$} & 55 & Uncontrolled rail-road crossing & Red & $\uparrow$ & - & $\uparrow$ & $\mathrm{N}$ & & $\checkmark$ & & & $\checkmark$ & 9 & 17 & - \\
\hline & 56 & $\begin{array}{l}\text { Poor junction readability - } \\
\text { Uncontrolled junctions }\end{array}$ & Yellow & - & $\downarrow$ & $\uparrow$ & $\mathrm{N}$ & $\checkmark$ & $\checkmark$ & $\checkmark$ & & $\checkmark$ & 8 & 25 & - \\
\hline & 58,59 & $\begin{array}{l}\text { Poor junction readability - } \\
\text { Absence of road markings and } \\
\text { crosswalks }\end{array}$ & Grey & - & - & $\uparrow$ & $\mathrm{N}$ & & $\checkmark$ & $\checkmark$ & & $\checkmark$ & 11 & 21 & $\begin{array}{l}\text { One synopsis was developed covering } \\
\text { the two risk factors of absence of road } \\
\text { markings and absence of marked } \\
\text { crosswalks. }\end{array}$ \\
\hline \multicolumn{2}{|c|}{ Total Numbers: } & Risk factor synopses: 39 & & \multicolumn{9}{|c|}{ Number of Studies $* * * *:$} & 320 & 1476 & : Number of Effects \\
\hline
\end{tabular}

* Crash risk: the number of crashes per unit of exposure. Crash frequency: the number of crashes. Crash severity: the severity of the injuries sustained by the casualties (fatal, serious, slight)

** Colour codes are: Red (Risky), Yellow (Probably risky), Grey (Unclear), Green (Probably not risky). Per each infrastructure element, risk factors are shown descending, from the highest risk (red colour code) to the lowest.

***These risk factors have more than one colour code, but for different road user types. The same studies were examined across different road users.

**** Several studies examined more than one risk factor. The number of unique studies is 243. 
Table 4. Meta-analysis results for the respective risk factors

\begin{tabular}{|l|l|c|c|c|c|}
\hline Risk factors (s/n) & $\begin{array}{l}\text { Meta-analysis } \\
\text { parameter (dependent } \\
\text { variable) }\end{array}$ & $\begin{array}{l}\text { Meta- } \\
\text { analysis } \\
\text { estimate }\end{array}$ & $\begin{array}{l}\text { Confidence } \\
\text { Interval } \\
\text { [95\%] }\end{array}$ & $\begin{array}{l}\text { Std. } \\
\text { Error }\end{array}$ & p-value \\
\hline $\begin{array}{l}\text { Presence of work zones - } \\
\text { Workzone length (\#16) }\end{array}$ & $\begin{array}{l}\text { Effect of work zone } \\
\text { length (in km) on crash } \\
\text { frequency }\end{array}$ & 0.862 & $(0.810,0.913)$ & 0.0261 & $<0.0001$ \\
\hline $\begin{array}{l}\text { Presence of work zones - } \\
\text { Workzone duration (\#17) }\end{array}$ & $\begin{array}{l}\text { Effect of work zone } \\
\text { duration (in days) on } \\
\text { crash frequency }\end{array}$ & 0.170 & $(-0.874,1.214)$ & 0.5327 & 0.7492 \\
\hline $\begin{array}{l}\text { Interchange deficiencies - } \\
\text { insufficient ramp length } \\
\text { (\#45) }\end{array}$ & $\begin{array}{l}\text { Effect of ramp length (in } \\
\text { km) on crash severity }\end{array}$ & 0.131 & $(-0.054,0.316)$ & 0.0944 & 0.1663 \\
\hline $\begin{array}{l}\text { Interchange deficiencies - } \\
\text { insufficient acceleration / } \\
\text { deceleration lane length } \\
\text { (\#46) }\end{array}$ & $\begin{array}{l}\text { Effect of deceleration } \\
\text { lane length (in km) on } \\
\text { crash frequency. }\end{array}$ & 0.216 & $(-0.256,0.687)$ & 0.2405 & 0.3701 \\
\cline { 2 - 6 } & $\begin{array}{l}\text { Effect of deceleration } \\
\text { lane length (in km) on } \\
\text { crash severity }\end{array}$ & -1.938 & $(-5.347,1.468)$ & 1.7380 & 0.2647 \\
\hline
\end{tabular}


Table 5. Vote-count analysis for the risk factor (\#26) 'presence of tunnel' (Ziakopoulos et al., 2016) (For interpretation of the references to colour in this table legend, the reader is referred to the web version of this article).

\begin{tabular}{|c|c|c|c|c|c|c|c|c|c|c|c|c|c|}
\hline \multirow{2}{*}{$\begin{array}{l}\text { Outcome } \\
\text { definition }\end{array}$} & \multirow{2}{*}{$\begin{array}{l}\text { Tested in } \\
\text { number of } \\
\text { studies }\end{array}$} & \multicolumn{3}{|c|}{$\begin{array}{l}\text { Result (number } \\
\text { of studies) }\end{array}$} & \multicolumn{3}{|c|}{ Result (\% of studies) } & \multicolumn{3}{|c|}{$\begin{array}{l}\text { Result (number } \\
\text { of effects) }\end{array}$} & \multicolumn{3}{|c|}{ Result (\% of effects) } \\
\hline & & $\uparrow$ & - & $\downarrow$ & $\uparrow$ & - & $\downarrow$ & $\uparrow$ & - & $\downarrow$ & $\uparrow$ & - & $\downarrow$ \\
\hline $\begin{array}{l}\text { Accident } \\
\text { frequency }\end{array}$ & 1 & 1 & - & - & $100.0 \%$ & - & - & 1 & - & 1 & $50.00 \%$ & - & $50.00 \%$ \\
\hline $\begin{array}{l}\text { Accident } \\
\text { numbers - rates }\end{array}$ & 2 & 1 & - & 1 & $50.00 \%$ & - & $50.00 \%$ & 2 & - & 4 & $33.33 \%$ & - & $66.67 \%$ \\
\hline Injury rates & 1 & 1 & - & - & $100.0 \%$ & - & - & 3 & - & 1 & $75.00 \%$ & - & $25.00 \%$ \\
\hline $\begin{array}{l}\text { Accident or } \\
\text { injury severity }\end{array}$ & 3 & 2 & 1 & - & $66.7 \%$ & $33 \cdot 3 \%$ & - & 9 & 1 & 2 & $75.00 \%$ & $8.33 \%$ & $16.67 \%$ \\
\hline $\begin{array}{l}\text { Behavioural } \\
\text { Safety Indicators } \\
\text { [Simulation] }\end{array}$ & 1 & - & - & 1 & - & - & $100.0 \%$ & 6 & 4 & 8 & $42.86 \%$ & - & $57.14 \%$ \\
\hline \multicolumn{8}{|l|}{ Total Studies $=8$} & \multicolumn{6}{|c|}{ Total Effects $=44$} \\
\hline
\end{tabular}


Table 6. Review type analysis for risk factor (\#30) 'number of lanes' (Loenis et al., 2016)

\begin{tabular}{|c|c|c|c|c|}
\hline $\begin{array}{l}\text { Author(s), } \\
\text { Year }\end{array}$ & Sample and study design & $\begin{array}{l}\text { Method of } \\
\text { analysis }\end{array}$ & $\begin{array}{l}\text { Outcome } \\
\text { indicator }\end{array}$ & Main result \\
\hline $\begin{array}{l}\text { Ahmed et al } \\
\text { (2011) }\end{array}$ & $\begin{array}{l}1877 \text { crashes from } 2000 \text { to } 2005 \text { collected } \\
\text { on } 168 \text { road segments. Data includes } \\
\text { AADT and roadway characteristics. Full } \\
\text { Bayesian study incorporating regression } \\
\text { modelling }\end{array}$ & $\begin{array}{l}\text { Poisson model, } \\
\text { spatial and random } \\
\text { effect Full Bayesian } \\
\text { model }\end{array}$ & Number of crashes & $\begin{array}{l}\text { A higher number of lanes } \\
\text { leads to significant decrease } \\
\text { of crashes }\end{array}$ \\
\hline $\begin{array}{l}\text { Rangel et al } \\
(2013)\end{array}$ & $\begin{array}{l}5525 \text { crashes from } 2007 \text { to } 2009 \text { collected } \\
\text { on } 696 \text { road segments, including } 1937 \\
\text { accidents, } 3480 \text { injuries and } 108 \\
\text { fatalities. Data includes AADT and } \\
\text { roadway characteristics. Cross-sectional } \\
\text { and observational study incorporating } \\
\text { regression modelling }\end{array}$ & $\begin{array}{l}\text { Negative Binomial } \\
\text { model }\end{array}$ & $\begin{array}{l}\text { Number of crashes } \\
\text { per crash severity } \\
\text { (accidents, injuries } \\
\text { and fatalities) }\end{array}$ & $\begin{array}{l}\text { A higher number of lanes } \\
\text { leads to significant increase } \\
\text { of crashes }\end{array}$ \\
\hline $\begin{array}{l}\text { Islam et. al } \\
(2014)\end{array}$ & $\begin{array}{l}751 \text { crashes from } 2009 \text { to } 2011 \text { collected } \\
\text { on } 949 \text { road segments, including } 237 \\
\text { single vehicle crashes and } 514 \text { multi } \\
\text { vehicle crashes. Data includes AADT and } \\
\text { roadway characteristics. Cross-sectional } \\
\text { study incorporating regression modelling }\end{array}$ & $\begin{array}{l}\text { CPM using a } \\
\text { negative binomial } \\
\text { distribution }\end{array}$ & $\begin{array}{l}\text { Number of crashes } \\
\text { per crash severity } \\
\text { (fatal and injurious } \\
\text { crashes) }\end{array}$ & $\begin{array}{l}\text { A higher number of lanes } \\
\text { leads to significant increase } \\
\text { of crashes. }\end{array}$ \\
\hline $\begin{array}{l}\text { Quddus } \\
(2013)\end{array}$ & $\begin{array}{l}3779 \text { crashes from } 2003 \text { to } 2007 \text { collected } \\
\text { on } 298 \text { road segments. Data includes } \\
\text { AADT and roadway characteristics. } \\
\text { Cross-sectional study incorporating } \\
\text { regression modelling }\end{array}$ & $\begin{array}{l}\text { Non-spatial } \\
\text { random-effect } \\
\text { Negative binomial } \\
\text { model and a spatial } \\
\text { Poisson lognormal } \\
\text { model using a full } \\
\text { hierarchical } \\
\text { Bayesian model for } \\
\text { exploring }\end{array}$ & $\begin{array}{l}\text { Number of crashes } \\
\text { per crash severity } \\
\text { (killed and severe } \\
\text { injuries, slight } \\
\text { injuries) }\end{array}$ & $\begin{array}{l}\text { A higher number of lanes } \\
\text { leads to significant increase } \\
\text { of crashes for all crash } \\
\text { severities }\end{array}$ \\
\hline $\begin{array}{l}\text { Chengye et al } \\
\text { (2013) }\end{array}$ & $\begin{array}{l}483 \text { crashes from } 2004 \text { to } 2010 \text { collected } \\
\text { on } 137 \text { road segments. Data includes } \\
\text { AADT and roadway characteristics. } \\
\text { Cross-sectional study incorporating } \\
\text { regression modelling }\end{array}$ & $\begin{array}{l}\text { Negative Binomial } \\
\text { models }\end{array}$ & $\begin{array}{l}\text { Number of crashes } \\
\text { per category (whole } \\
\text { motorway, urban } \\
\text { and rural segments, } \\
\text { with off-ramp or on- } \\
\text { ramp and without } \\
\text { ramps) }\end{array}$ & $\begin{array}{l}\text { A higher number of lanes } \\
\text { leads to significant increase } \\
\text { of crashes for all categories }\end{array}$ \\
\hline
\end{tabular}




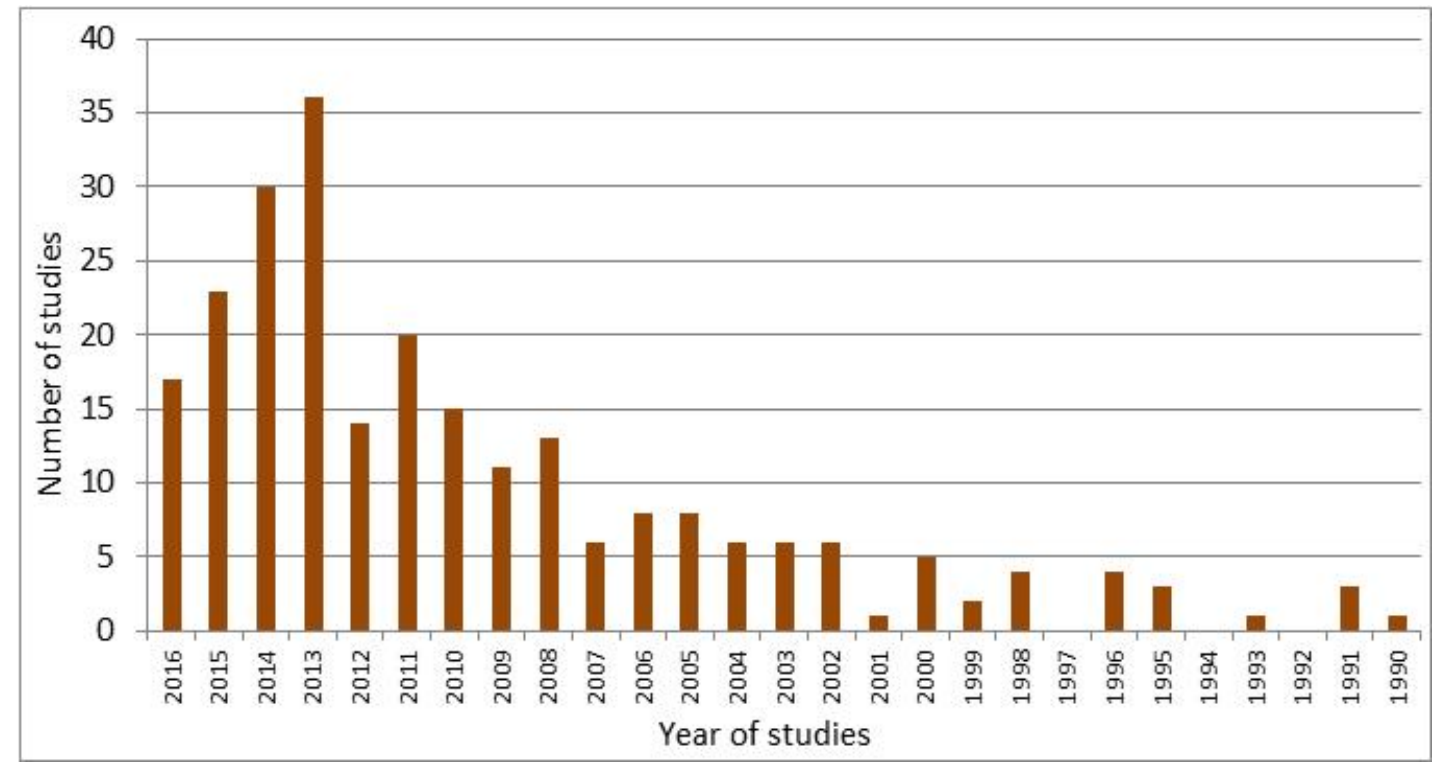

Figure 1. Year of publication of coded studies on infrastructure risk factors $(N=243$ studies) 


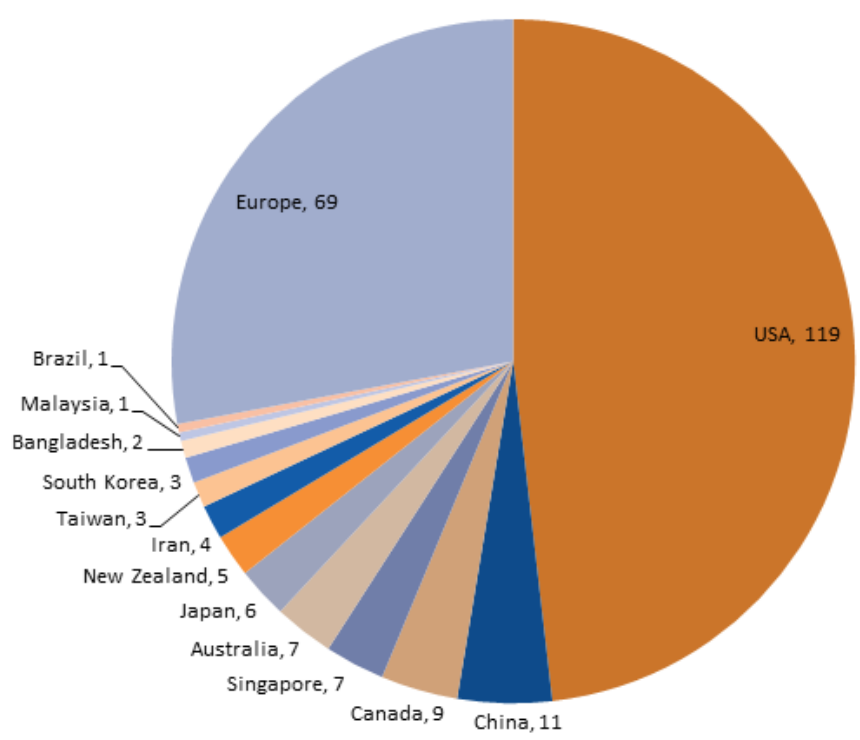

Note: several studies originate from more than one country

Figure 2. Number of coded studies originating from countries across Europe and the rest of the world ( $N=243$ studies) 


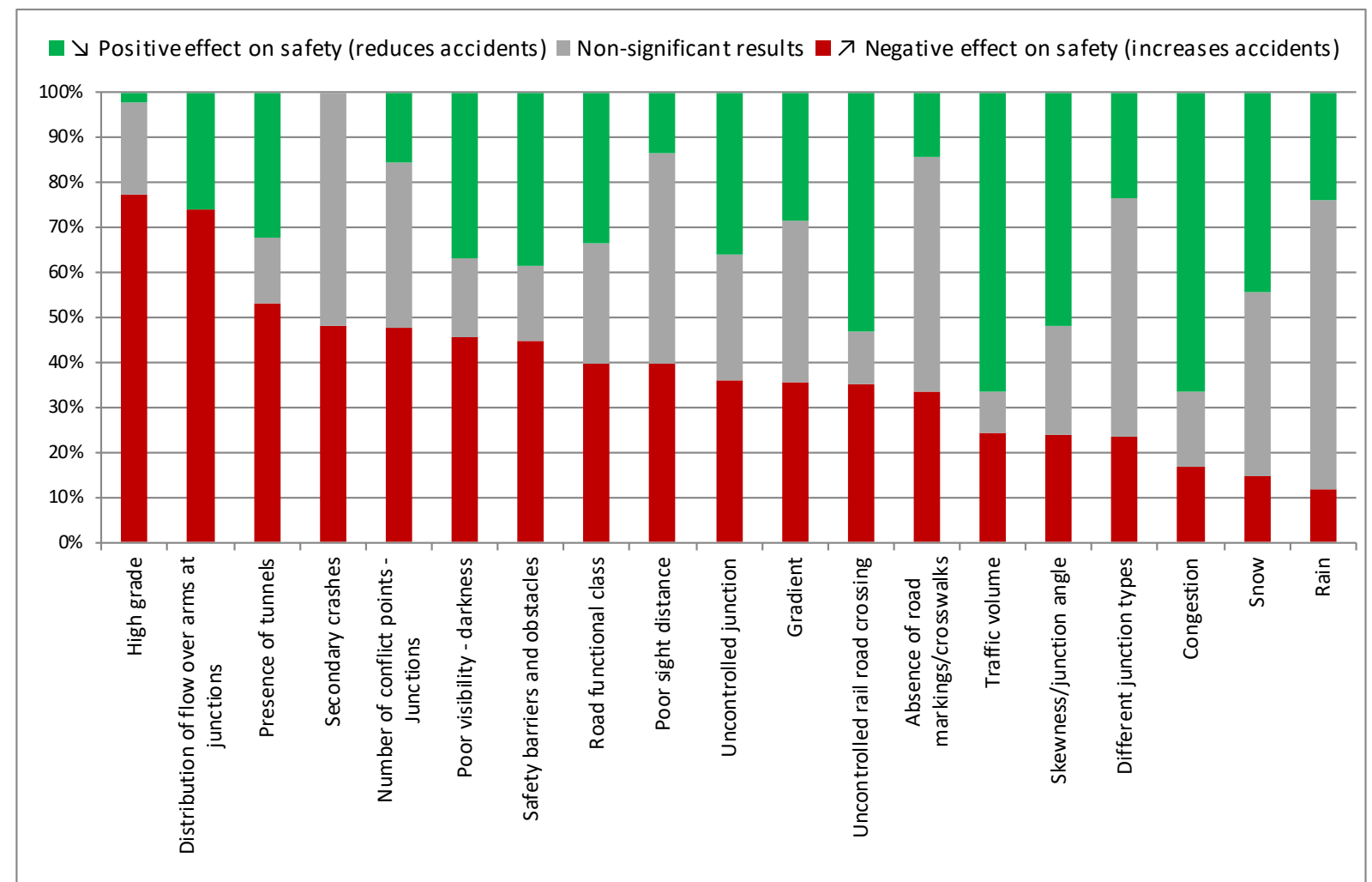

Figure 3. Results of vote-count analyses - Share of positive and negative effects identified for infrastructure-related risk factors. 


\begin{tabular}{|c|c|c|c|}
\hline $\begin{array}{l}\text { Red } \\
\text { (Risky) }\end{array}$ & $\begin{array}{l}\text { Yellow } \\
\text { (Probably risky) }\end{array}$ & $\begin{array}{l}\text { Green } \\
\text { (Probably not risky) }\end{array}$ & $\begin{array}{l}\text { Grey } \\
\text { (Unclear) }\end{array}$ \\
\hline 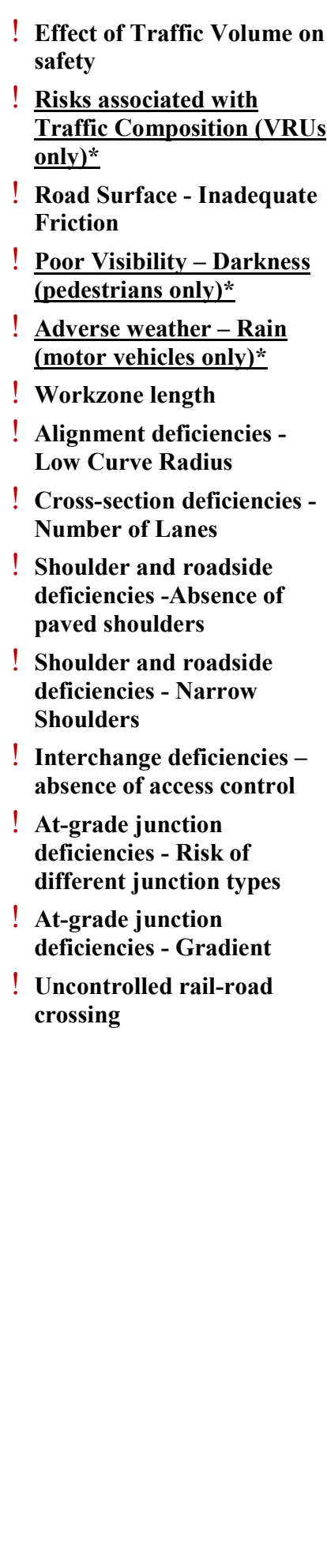 & $\begin{array}{l}\text { ! Congestion as a risk } \\
\text { factor } \\
\text { ! Occurrence of Secondary } \\
\text { crashes } \\
\text { ! Alignment deficiencies - } \\
\text { Absence of Transition } \\
\text { curves } \\
\text { ! Road functional class } \\
\text { ! Poor Visibility - } \\
\text { Darkness (all and two- } \\
\text { wheelers only) } \\
\text { ! Poor visibility - fog } \\
\text { ! Adverse weather - Rain } \\
\text { (all)* } \\
\text { ! Workzone duration } \\
\text { ! Alignment deficiencies - } \\
\text { High grade } \\
\text { ! Presence of Tunnels } \\
\text { ! Cross-section } \\
\text { deficiencies - } \\
\text { Superelevation } \\
\text { ! Cross-section } \\
\text { deficiencies - Narrow } \\
\text { lanes } \\
\text { ! Undivided road } \\
\text { ! Cross-section } \\
\text { deficiencies - Narrow } \\
\text { median } \\
\text { ! Shoulder and roadside } \\
\text { deficiencies - Risks } \\
\text { associated with Safety } \\
\text { Barriers and Obstacles } \\
\text { ! Aeficiencies - Poor sight } \\
\text { ! Phoulder and roadside } \\
\text { deficiencies - Sight } \\
\text { - Uncontroliod junction readability } \\
\text { Obstructions (Landscape, } \\
\text { Obstacles and } \\
\text { Vegetation) } \\
\text { ! At-grade junctions } \\
\text { deficiencies - Number of } \\
\text { conflict points } \\
\text { ! At-grade junction } \\
\text { deficiencies - Skewness / }\end{array}$ & $\checkmark \frac{\text { Poor Visibility - }}{\text { Darkness (cars only)* }}$ & $\begin{array}{l}\text { ? Risks associated with } \\
\underline{\text { Traffic Composition }} \\
\text { (HGVs only)* } \\
\text { ? Risks associated with } \\
\text { the distribution of } \\
\text { traffic flow over arms } \\
\text { at junctions } \\
\text { ? Adverse weather - } \\
\text { Rain (other road users } \\
\text { only)* } \\
\text { ? Adverse weather - } \\
\text { Frost and snow } \\
\text { ? Alignment deficiencies } \\
\text { - Frequent curves } \\
\text { ? Alignment deficiencies } \\
\text { - Densely spaced } \\
\text { junctions } \\
\text { ? Interchange } \\
\text { deficiencies - Ramp } \\
\text { Length } \\
\text { ? Interchange } \\
\text { deficiencies - } \\
\text { Acceleration / } \\
\text { deceleration lane length } \\
\text { ? Poor junction } \\
\text { readability - Absence } \\
\text { of road markings and } \\
\text { crosswalks }\end{array}$ \\
\hline
\end{tabular}

*The risk factors which are underlined have more than one colour code, but for different road user types.

Figure 4. Infrastructure related risk factors ranking by colour code ( $N=39$ synopses). 


\section{Appendix A. Taxonomy and definitions of road infrastructure risk factors}

\begin{tabular}{|c|c|c|c|c|}
\hline $\begin{array}{l}\text { Infrastructure } \\
\text { element }\end{array}$ & $\begin{array}{l}\text { General } \\
\text { risk factor }\end{array}$ & $\mathbf{s} / \mathbf{n}$ & Specific risk factor & Definition / explanation \\
\hline \multirow{5}{*}{ Exposure } & \multirow{5}{*}{ Traffic flow } & 1 & Effect of traffic volume on road safety & $\begin{array}{l}\text { Crash risk increases due to } \\
\text { increases in traffic flow, which } \\
\text { is the number of vehicles on the } \\
\text { street per time unit }\end{array}$ \\
\hline & & 2 & Congestion as a risk factor & $\begin{array}{l}\text { Crash increases from a traffic } \\
\text { state with slow-moving or still- } \\
\text { standing traffic }\end{array}$ \\
\hline & & 3 & Occurrence of secondary crashes & $\begin{array}{l}\text { Crash increases from an } \\
\text { occurrence of an initial (earlier) } \\
\text { crash or incident }\end{array}$ \\
\hline & & 4 & $\begin{array}{l}\text { Risks associated with varying traffic } \\
\text { composition (share of pedestrians, } \\
\text { cyclists, PTW, HGV) }\end{array}$ & $\begin{array}{l}\text { Crash risk increases due to } \\
\text { increases in the proportions of } \\
\text { cyclists, pedestrians and/or } \\
\text { heavier vehicles in traffic flows }\end{array}$ \\
\hline & & 5 & $\begin{array}{l}\text { Risks associated with the distribution of } \\
\text { flow over arms at junctions }\end{array}$ & $\begin{array}{l}\text { Crash risk induced in the case } \\
\text { where primary and secondary } \\
\text { roads converge resulting in an } \\
\text { unbalanced distribution of } \\
\text { traffic flow over the arms of a } \\
\text { junction }\end{array}$ \\
\hline Road type & $\begin{array}{l}\text { Road } \\
\text { functional } \\
\text { class }\end{array}$ & 6 & Road functional class & $\begin{array}{l}\text { Implementation and use of } \\
\text { different road types and the } \\
\text { differences in crash and injury } \\
\text { rates between these road } \\
\text { classes. }\end{array}$ \\
\hline \multirow{4}{*}{ Road surface } & \multirow{4}{*}{$\begin{array}{l}\text { Road } \\
\text { surface } \\
\text { deficiencies }\end{array}$} & 7 & Inadequate friction & $\begin{array}{l}\text { Crash risk increases due to } \\
\text { subpar road (pavement) surface } \\
\text { friction resulting in reduced } \\
\text { tyre grip efficiency on the road }\end{array}$ \\
\hline & & 8 & Uneven surface & $\begin{array}{l}\text { Crash risk increases due uneven } \\
\text { road pavement surface }\end{array}$ \\
\hline & & 9 & Ice, snow & $\begin{array}{l}\text { Crash risk increases due to ice } \\
\text { and snow on the road surface }\end{array}$ \\
\hline & & 10 & Oil, leaves, etc. & $\begin{array}{l}\text { Crash risk increases due to oil, } \\
\text { leaves and other slippery } \\
\text { elements on the road surface }\end{array}$ \\
\hline \multirow{5}{*}{$\begin{array}{l}\text { Road } \\
\text { environment }\end{array}$} & \multirow{2}{*}{$\begin{array}{l}\text { Poor } \\
\text { visibility }\end{array}$} & 11 & Darkness & $\begin{array}{l}\text { Crash risk increases due to } \\
\text { darkness and absence of } \\
\text { illumination }\end{array}$ \\
\hline & & 12 & Fog & $\begin{array}{l}\text { Crash risk increases due to fog } \\
\text { on the road }\end{array}$ \\
\hline & \multirow{3}{*}{$\begin{array}{l}\text { Adverse } \\
\text { weather }\end{array}$} & 13 & Rain & $\begin{array}{l}\text { Crash risk increases due to rain } \\
\text { and wet pavements }\end{array}$ \\
\hline & & 14 & Snow \& frost & $\begin{array}{l}\text { Crash risk increases due to } \\
\text { snow and frost on the road } \\
\text { environment }\end{array}$ \\
\hline & & 15 & Wind & $\begin{array}{l}\text { Crash risk increases due to } \\
\text { wind effects on vehicles and } \\
\text { infrastructure }\end{array}$ \\
\hline \multirow{3}{*}{ Workzones } & \multirow{3}{*}{$\begin{array}{l}\text { Presence of } \\
\text { workzones }\end{array}$} & 16 & Workzone length & $\begin{array}{l}\text { Crash risk increases due to } \\
\text { increased length of workzone } \\
\text { (roadworks) areas }\end{array}$ \\
\hline & & 17 & Workzone duration & $\begin{array}{l}\text { Crash risk increases due to } \\
\text { increased time duration of } \\
\text { workzone (roadworks) areas }\end{array}$ \\
\hline & & 18 & Insufficient signage & $\begin{array}{l}\text { Crash risk increases due to } \\
\text { inadequate signage and } \\
\text { delineation of workzone } \\
\text { (roadworks) areas }\end{array}$ \\
\hline $\begin{array}{l}\text { Alignment - } \\
\text { Road segments }\end{array}$ & $\begin{array}{l}\text { Horizontal / } \\
\text { vertical }\end{array}$ & 19 & $\begin{array}{l}\text { Alignment deficiencies - Low curve } \\
\text { radius }\end{array}$ & $\begin{array}{l}\text { Crash risk increases due to low } \\
\text { radius of turning road curves } \\
\text { (sharp turns) }\end{array}$ \\
\hline
\end{tabular}




\begin{tabular}{|c|c|c|c|c|}
\hline $\begin{array}{l}\text { Infrastructure } \\
\text { element }\end{array}$ & $\begin{array}{l}\text { General } \\
\text { risk factor }\end{array}$ & $\mathbf{s} / \mathbf{n}$ & Specific risk factor & Definition / explanation \\
\hline & $\begin{array}{l}\text { alignment } \\
\text { deficiencies }\end{array}$ & 20 & $\begin{array}{l}\text { Alignment deficiencies - Absence of } \\
\text { transition curves }\end{array}$ & $\begin{array}{l}\text { Crash risk increases due to poor } \\
\text { design of infrastructure which } \\
\text { excludes transition curves } \\
\text { between straight and circular } \\
\text { sections of roads }\end{array}$ \\
\hline & & 21 & $\begin{array}{l}\text { Alignment deficiencies - Frequent } \\
\text { curves }\end{array}$ & $\begin{array}{l}\text { Crash risk increases due to } \\
\text { highly frequent interchanging } \\
\text { separate curves and turns on the } \\
\text { road }\end{array}$ \\
\hline & & 22 & $\begin{array}{l}\text { Alignment deficiencies - Densely } \\
\text { spaced junctions }\end{array}$ & $\begin{array}{l}\text { Crash risk increases due to } \\
\text { highly frequent presence of } \\
\text { junctions along the road }\end{array}$ \\
\hline & & 23 & Poor sight distance - horizontal curves & $\begin{array}{l}\text { Crash risk increases due to } \\
\text { limited visibility because of } \\
\text { horizontal road curvature }\end{array}$ \\
\hline & & 24 & Alignment deficiencies - High grade & $\begin{array}{l}\text { Crash risk increases due to high } \\
\text { degrees of slopes (gradients; } \\
\text { both ascending and descending) } \\
\text { of road segments }\end{array}$ \\
\hline & & 25 & $\begin{array}{l}\text { Alignment deficiencies - Vertical curve } \\
\text { radius }\end{array}$ & $\begin{array}{l}\text { Crash risk increases due to } \\
\text { limited radius of vertical road } \\
\text { curvature }\end{array}$ \\
\hline & & 26 & Presence of Tunnel & $\begin{array}{l}\text { Crash risk increases due to } \\
\text { tunnels along the road }\end{array}$ \\
\hline & & 27 & Poor sight distance - vertical curves & $\begin{array}{l}\text { Crash risk increases due to } \\
\text { limited visibility because of } \\
\text { vertical road curvature }\end{array}$ \\
\hline \multirow{8}{*}{$\begin{array}{l}\text { Cross-section - } \\
\text { Road segments }\end{array}$} & \multirow{2}{*}{$\begin{array}{l}\text { Super } \\
\text { elevation / } \\
\text { cross-slopes }\end{array}$} & 28 & $\begin{array}{l}\text { Cross section deficiencies - } \\
\text { Superelevation at curve }\end{array}$ & $\begin{array}{l}\text { Superelevation refers to the } \\
\text { right-angled slope of the road } \\
\text { surface and is part of the } \\
\text { horizontal curve design. A } \\
\text { deficient superelevation relates } \\
\text { to a related increase in crashes. }\end{array}$ \\
\hline & & 29 & Cross section deficiencies - Cross-slope & $\begin{array}{l}\text { Cross-slope refers to the the } \\
\text { transverse slope with respect to } \\
\text { the horizon. A deficient cross- } \\
\text { slope relates to a related } \\
\text { increase in crashes. }\end{array}$ \\
\hline & \multirow{2}{*}{$\begin{array}{l}\text { Lanes / } \\
\text { ramps } \\
\text { deficiencies }\end{array}$} & 30 & $\begin{array}{l}\text { Cross section deficiencies - Number of } \\
\text { lanes }\end{array}$ & $\begin{array}{l}\text { Crash risk fluctuations based on } \\
\text { different configurations of lane } \\
\text { numbers on the road }\end{array}$ \\
\hline & & 31 & $\begin{array}{l}\text { Cross section deficiencies - Narrow } \\
\text { lane }\end{array}$ & $\begin{array}{l}\text { Crash risk increases due to road } \\
\text { lanes being too narrow and } \\
\text { harder to follow }\end{array}$ \\
\hline & \multirow{2}{*}{$\begin{array}{l}\text { Median / } \\
\text { barrier } \\
\text { deficiencies } \\
\text { (risk of } \\
\text { crash with } \\
\text { oncoming } \\
\text { traffic) }\end{array}$} & 32 & Undivided road & $\begin{array}{l}\text { Crash risk increases due to } \\
\text { conflicts of traffic from } \\
\text { opposite directions due to lack } \\
\text { of division (separation with a } \\
\text { barrier) on bidirectional roads }\end{array}$ \\
\hline & & 33 & $\begin{array}{l}\text { Cross section deficiencies - Narrow } \\
\text { median }\end{array}$ & $\begin{array}{l}\text { Crash risk increases due to } \\
\text { medians being too narrow and } \\
\text { allowing impacts to cross } \\
\text { directions }\end{array}$ \\
\hline & \multirow{2}{*}{$\begin{array}{l}\text { Shoulder } \\
\text { and } \\
\text { roadside } \\
\text { deficiencies }\end{array}$} & 34 & Absence of shoulder & $\begin{array}{l}\text { Crash risk increases due to } \\
\text { shoulders on the outer sides of } \\
\text { the road not being paved } \\
\text { (usually gravel or dirt) }\end{array}$ \\
\hline & & 35 & Narrow shoulder & $\begin{array}{l}\text { Crash risk increases due to } \\
\text { shoulders on the outer sides of } \\
\text { the road being too narrow and } \\
\text { allow less space to maneuver } \\
\text { back (e.g. in a run-off-road } \\
\text { crash) }\end{array}$ \\
\hline
\end{tabular}




\begin{tabular}{|c|c|c|c|c|}
\hline $\begin{array}{l}\text { Infrastructure } \\
\text { element }\end{array}$ & $\begin{array}{l}\text { General } \\
\text { risk factor }\end{array}$ & $\mathbf{s} / \mathbf{n}$ & Specific risk factor & Definition / explanation \\
\hline & & 36 & $\begin{array}{l}\text { Roadside deficiencies - Absence of } \\
\text { guardrails or crash cushions }\end{array}$ & $\begin{array}{l}\text { Crash risk increases due to } \\
\text { unprotected sides of rural or } \\
\text { urban arterial roads }\end{array}$ \\
\hline & & 37 & $\begin{array}{l}\text { Roadside deficiencies - Absence of } \\
\text { clear-zone }\end{array}$ & $\begin{array}{l}\text { Crash risk increases due to not } \\
\text { allowing for space for } \\
\text { shoulders on the outer sides of } \\
\text { the road }\end{array}$ \\
\hline & & 38 & $\begin{array}{l}\text { Roadside deficiencies - Roadside } \\
\text { obstacles (per type of obstacle e.g. } \\
\text { trees) }\end{array}$ & $\begin{array}{l}\text { Crash risk increases due to } \\
\text { drivers having limited line of } \\
\text { sight due to obstructing objects, } \\
\text { such as such as landscape } \\
\text { layout, vegetation by the road, } \\
\text { and other obstacles }\end{array}$ \\
\hline & & 39 & $\begin{array}{l}\text { Roadside deficiencies - Risks } \\
\text { associated with Safety Barriers }\end{array}$ & $\begin{array}{l}\text { Crash risk increases due to } \\
\text { drivers colliding with safety } \\
\text { barriers which are acting as an } \\
\text { obstacle in this case }\end{array}$ \\
\hline \multirow{4}{*}{$\begin{array}{l}\text { Traffic control } \\
\text { - Road } \\
\text { segments }\end{array}$} & \multirow{4}{*}{$\begin{array}{l}\text { Poor road } \\
\text { readability }\end{array}$} & 40 & Absence of traffic signs & $\begin{array}{l}\text { Crash risk increases due to } \\
\text { absent traffic signs at road } \\
\text { segments }\end{array}$ \\
\hline & & 41 & Misleading or unreadable traffic signs & $\begin{array}{l}\text { Crash risk increases due to } \\
\text { traffic signs not being } \\
\text { comprehended by road users at } \\
\text { road segments because they are } \\
\text { misleading or unreadable }\end{array}$ \\
\hline & & 42 & Absence of road markings & $\begin{array}{l}\text { Crash risk increases due to } \\
\text { absence or presence of road } \\
\text { markings in road segments }\end{array}$ \\
\hline & & 43 & Absence of rumble strips & $\begin{array}{l}\text { Crash risk increases due to } \\
\text { absence of rumble strips in road } \\
\text { segments where they are } \\
\text { applicable }\end{array}$ \\
\hline \multirow{8}{*}{$\begin{array}{l}\text { Alignment - } \\
\text { Junctions }\end{array}$} & \multirow{6}{*}{$\begin{array}{l}\text { Interchange } \\
\text { deficiencies }\end{array}$} & 44 & Ramp capacity & $\begin{array}{l}\text { Crash risk increases due to } \\
\text { inadequate vehicle capacity of } \\
\text { ramp lengths in an interchange } \\
\text { or junction }\end{array}$ \\
\hline & & 45 & Ramp length & $\begin{array}{l}\text { Crash risk increases due to } \\
\text { inadequate access ramp lengths } \\
\text { in an interchange or junction }\end{array}$ \\
\hline & & 46 & Acceleration / deceleration lane length & $\begin{array}{l}\text { Crash risk increases due to } \\
\text { inadequate acceleration- } \\
\text { deceleration lane lengths in an } \\
\text { interchange }\end{array}$ \\
\hline & & 47 & Absence of channelization & $\begin{array}{l}\text { Crash risk increases due to } \\
\text { absence of channelisation of } \\
\text { junctions }\end{array}$ \\
\hline & & 48 & Absence of access control & $\begin{array}{l}\text { Crash risk increases due to no } \\
\text { measures to reduce the number } \\
\text { of (private) driveways along a } \\
\text { public road. }\end{array}$ \\
\hline & & 49 & Poor sight distance & $\begin{array}{l}\text { Crash risk increases due to } \\
\text { limited sight distance at } \\
\text { junctions }\end{array}$ \\
\hline & \multirow{2}{*}{$\begin{array}{l}\text { At-grade } \\
\text { junctions } \\
\text { deficiencies }\end{array}$} & 50 & High number of conflict points & $\begin{array}{l}\text { Crash risk increases due to the } \\
\text { number of conflict points at } \\
\text { junctions, mostly expressed } \\
\text { through the (total) number of } \\
\text { lanes }\end{array}$ \\
\hline & & 51 & Type of junction & $\begin{array}{l}\text { Crash risk (or severity) } \\
\text { increases due to different } \\
\text { junction types (either four or } \\
\text { more legs compared to 3- } \\
\text { legged junctions) }\end{array}$ \\
\hline
\end{tabular}




\begin{tabular}{|c|c|c|c|c|}
\hline $\begin{array}{l}\text { Infrastructure } \\
\text { element }\end{array}$ & $\begin{array}{l}\text { General } \\
\text { risk factor }\end{array}$ & $\mathbf{s} / \mathbf{n}$ & Specific risk factor & Definition / explanation \\
\hline & & 52 & Skewness / junction angle & $\begin{array}{l}\text { Crash risk increases due to non- } \\
\text { perpendicular road axes at } \\
\text { junctions, resulting in junction } \\
\text { angles different from } 90^{\circ}\end{array}$ \\
\hline & & 53 & Poor sight distance & $\begin{array}{l}\text { Crash risk increases due to poor } \\
\text { sight distance for drivers due to } \\
\text { subpar junction design }\end{array}$ \\
\hline & & 54 & Gradient & $\begin{array}{l}\text { Crash risk increases due to high } \\
\text { degrees of slopes at junctions }\end{array}$ \\
\hline \multirow{5}{*}{$\begin{array}{l}\text { Traffic control } \\
\text { - Junctions }\end{array}$} & $\begin{array}{l}\text { Rail-road } \\
\text { crossings }\end{array}$ & 55 & Uncontrolled rail-road crossing & $\begin{array}{l}\text { Crash risk increases due to } \\
\text { crossings between road and rail } \\
\text { infrastructure which are } \\
\text { uncontrolled (passive), without } \\
\text { any barriers }\end{array}$ \\
\hline & \multirow{4}{*}{$\begin{array}{l}\text { Poor } \\
\text { junction } \\
\text { readability }\end{array}$} & 56 & Uncontrolled junction & $\begin{array}{l}\text { Crash risk increases due to } \\
\text { junctions where no traffic } \\
\text { lights, road markings or signs } \\
\text { are used to indicate the right-of- } \\
\text { way }\end{array}$ \\
\hline & & 57 & Misleading or unreadable traffic sign & $\begin{array}{l}\text { Crash risk increases due to } \\
\text { traffic signs not being } \\
\text { comprehended by road users at } \\
\text { junctions because they are } \\
\text { misleading or unreadable }\end{array}$ \\
\hline & & 58 & Absence of road markings & $\begin{array}{l}\text { Crash risk increases due to } \\
\text { absence or presence of road } \\
\text { markings at road segments }\end{array}$ \\
\hline & & 59 & Absence of marked crosswalks & $\begin{array}{l}\text { Crash risk increases due to } \\
\text { absence or presence of road } \\
\text { markings in junctions, both } \\
\text { overall and at crosswalks }\end{array}$ \\
\hline
\end{tabular}

